\title{
Prescribed versus wildfire impacts on exotic plants and soil microbes in California grasslands
}

Authors: Sydney I Glassman ${ }^{1}$, James WJ Randolph ${ }^{1}$, Sameer S Saroa ${ }^{2}$, Joia K Capocchi ${ }^{3}$, Kendra E Walters ${ }^{3}$, M. Fabiola Pulido-Chavez ${ }^{1}$, Loralee Larios ${ }^{2}$

Author affiliations: ${ }^{1}$ Department of Microbiology and Plant Pathology, University of California, Riverside, CA 92521; ${ }^{2}$ Department of Botany and Plant Sciences, University of California, Riverside, CA 92521; ${ }^{3}$ Department of Ecology and Evolutionary Biology, University of California, Irvine, CA 92697

Corresponding author email: sydneyg@ucr.edu

Key words: California grasslands, prescribed fire, Tenaja fire, bacteria, fungi, invasive plants 


\section{Abstract:}

2 1. Prescribed fire is often used as a management tool to decrease exotic plant cover and increase native plant cover in grasslands. These changes may also be mediated by fire impacts on soil microbial communities, which drive plant productivity and function. Yet, the ecological effects of prescribed burns compared to wildfires on either plant or soil microbial composition remain unclear.

2. Here, we investigated the impacts of a spring prescribed fire versus a fall wildfire on plant cover and community composition and bacterial and fungal richness, abundance, and

9
composition in a California grassland. We used qPCR of $16 \mathrm{~S}$ and $18 \mathrm{~S}$ to assess impacts on

12 3. Wildfire had stronger impacts than prescribed fire on microbial communities and both fires had similar impacts on plants with both prescribed and wildfire reducing exotic plant cover

17 altered bacterial and fungal composition.

18 4. Exotic and native plant diversity differentially affected soil microbial diversity, with native 19 plant diversity leading to increased arbuscular mycorrhizal fungal richness while exotic plant 20 diversity better predicted bacterial richness. However, the remainder of the soil microbial 21 communities were more related to aspects of soil chemistry including cation exchange 22 capacity, organic matter, $\mathrm{pH}$ and phosphorous. 
23 5. Synthesis and applications. Understanding the different ecological effects of prescribed fires

24 and wildfires on plant and soil communities are key to enhancing a prevalent management

25 action and to guide potential management opportunities post wildfires. Our coupled plant and

26 soil community sampling allowed us to capture the sensitivity of the fungal community to

27 fire and highlights the importance of potentially incorporating management actions such as

28 soil or fungal amendments to promote this critical community that mediates native plant

29 performance.

31 Introduction:

Land managers increasingly need to grapple with the effects of fire on their management

33 objectives, particularly in the Western United States, where prescribed burns and wildfires are

34 becoming more frequent (Running 2006; Westerling et al. 2006; Ryan, Knapp \& Varner 2013).

35 Comparisons between the effects of prescribed burns and wildfires have centered on forests

36 where long-term fire suppression has altered the baseline conditions and can create undesirable

37 negative effects (Ryan, Knapp \& Varner 2013). However, similarities between prescribed burns

38 and wildfires in other systems, such as grasslands, have yet to be fully explored. Within

39 grasslands, leveraging insights from cultural burning practices, land managers are using

40 prescribed burns as a management tool to reduce the negative impacts of exotic species and

41 increase native plant establishment and performance (Blackburn \& Anderson 1993; McKemey et

42 al. 2020). Prescribed fires typically occur in spring, under higher moisture conditions that

43 minimize fire spread and intensity (Ryan, Knapp \& Varner 2013). In contrast, wildfires in the

44 America West historically occur during the summer and fall, under drier fuel conditions

45 (Stephens \& Collins 2004), thus leading to more intense burns. This difference in burn intensity 
46 may be a key factor in the beneficial management outcomes of prescribed burns (Knapp, Estes \&

47 Skinner 2009), but native plant species performance is not consistently enhanced in prescribed

48 burns and can be negatively affected by wildfires (Alba et al. 2015). Therefore, more studies are

49 needed that compare the ecological effects of prescribed burns and wildfires in grasslands to

50 improve the use of fire as a management tool.

51 The impacts of fire for land management have classically focused on native plant

52 recovery but have overlooked the impacts that the soil microbial communities may have on

53 vegetation recovery. Soil microbes are critical drivers of all major biogeochemical cycles

54 (Crowther et al. 2019) and plant diversity and productivity (van der Heijden et al. 1998). Thus,

55 their resilience, or rate of return to the undisturbed state (Shade et al. 2012), after fire may be

56 critical to the regeneration of aboveground vegetation. Fungi, in particular, likely play critical

57 roles in plant regeneration since up to to $90 \%$ of plant species are associated with mycorrhizal

58 fungal symbionts that increase access to nutrients in exchange for carbon (Brundrett \& Tedersoo

59 2018). Arbuscular mycorrhizal fungi (AMF) are particularly important in driving grassland

60 dynamics (van der Heijden et al. 2006), and AMF often co-occur with soil bacteria and fungi that

61 may be critical to plant growth, plant productivity, and the cycling of nutrients (Garbaye 1994;

62 Yuan et al. 2021). Despite the importance of plant-AMF coupling in mediating plant

63 successional dynamics (Kardol, Bezemer \& van der Putten 2006; Cheeke et al. 2019), the

64 impacts of fires on soil microbes in grasslands remains understudied (Pressler, Moore \& Cotrufo 65 2019).

How prescribed burns versus wildfires affect soil microbial resilience may critically

67 impact native plant regeneration. Fires typically reduce soil microbial biomass (Dooley \&

68 Treseder 2012) and richness (Pressler, Moore \& Cotrufo 2019), and alter the richness and 
69 composition of mycorrhizal fungal symbionts (Dove \& Hart 2017). A meta-analysis of

70 belowground impacts of fires found that only $12 \%$ of studies focused on grasslands (Pressler,

71 Moore \& Cotrufo 2019), even though roughly 80\% of fires globally occur in grasslands each

72 year (Leys et al. 2018). While a review found that prescribed fires and wildfires have similar

73 impacts on fungal biomass in grasslands (Pressler, Moore \& Cotrufo 2019), the impacts of

74 prescribed fires versus wildfires on grassland bacterial biomass, microbial richness, or

75 composition remain unknown. The lower fuel load in grassland typically results in fast-moving

76 low severity wildfires. Soil microbes are more resilient to less severe fires (Holden et al. 2016),

77 thus, fires in grasslands, whether prescribed or wildfire, might not be severe enough to

78 significantly alter soil microbial communities.

79 Exotic plant species, which are often the impetus for prescribed burns (Knapp, Estes \&

80 Skinner 2009), may create soil legacies that limit the recovery of native species (Kulmatiski et

81 al. 2008). These soil legacies may interact with disturbances such as fire to synergistically reduce

82 native plant performance (Suding et al. 2013). For example, many exotic plant species succeed

83 and become invasive through reduced reliance on mycorrhizal symbionts (Pringle et al. 2009) or

84 by suppressing native symbiotic communities in an invaded area (Mummey \& Rillig 2006;

85 Vogelsang \& Bever 2009; Zubek et al. 2016), thus promoting the growth of invasive plant

86 species over resident native species. Alternatively, exotic plant species may alter the soil

87 microbial community by enhancing pathogens (Eppinga et al. 2006) or promoting soil

88 communities that enhance resource acquisition (Hawkes et al. 2006). These dynamics can result

89 in a positive feedback loop (Callaway et al. 2004; Kulmatiski et al. 2008) and may interact with

90 disturbances to further promote the performance of exotic species (Suding et al. 2013). They can

91 also limit the outcomes of restoration efforts for native plant species (Lankau et al. 2014). 
92 Therefore, understanding the resilience of the soil microbial community in an invaded grassland

93 is key to identifying and refining further management efforts.

California grasslands are an ideal system to explore these dynamics. Prescribed fires are

95 an important management tool for reducing the dominance of exotic species in once biodiverse

96 native perennial grasslands (Menke 1992; Dyer 2002; DiTomaso et al. 2006). When used as a

97 restoration tool, prescribed burns have had mixed effects in helping to eliminate noxious weeds,

98 especially in systems where invasive annual grasses within the genera Avena and Bromus

99 outcompete native perennial bunchgrass, thus failing to promote native plant species

100 establishment (Holmes \& Rice 1996; Meyer \& Schiffman 1999; D’Antonio et al. 2002; Corbin

101 \& D'Antonio 2010). These annual grasses can differentially impact biogeochemical cycling and

102 soil communities for their benefit (Hawkes et al. 2005; Eviner \& Hawkes 2008; Vogelsang \&

103 Bever 2009). However, soil amendments to offset the impacts of these invaders can result in

104 positive native plant responses (Sandel, Corbin \& Krupa 2011; Emam 2016). Together, these

105 dynamics suggest that a closer investigation of how soil microbial communities are changing

106 with fire may provide some insight into improving the efficacy of grassland management.

107 Here, we explore the impacts of a prescribed fire versus a wildfire that burned through

108 remnant perennial grassland in Southern California. Prescribed fires, which typically occur in

109 spring, are used as a management tool to reduce nonnative species cover and to retain cover of

110 the native perennial bunchgrass Stipa pulchra in Southern California grasslands (Valliere et al.

111 2019), but summer and fall wildfires also typically occur in California grasslands every 2-6 years

112 (Fryer \& Luensmann 2012). We coupled time-series sampling of the soil microbial community

113 with plant recovery data to ask how prescribed fire versus wildfire impacts: 1) native versus

114 exotic plant cover and richness 2) soil bacterial and fungal biomass and richness 3) soil bacterial 
and fungal composition over time, and finally, 4) how does AMF and soil microbial regeneration

116 relate to native plant regeneration?

\section{Materials and Methods:}

Description of field site: Field work was conducted at the Santa Rosa Plateau Ecological

120 Reserve, Riverside County, CA, USA in the location of the Burro Burn unit and the Tenaja

121 wildfire (Table S1). The reserve consists of expanses of grassland intermixed with chaparral,

122 coastal sage scrub, and oak woodlands (Valliere et al. 2019) situated in a Mediterranean climate

123 with dry summers and where most precipitation falls from October through May. Precipitation

124 for the 2018-19 growing season was approximately $648 \mathrm{~mm}$ and 506mm for 2019-2020. Both

125 soils are Alfisols with the soil at the Tenaja site belonging to the Vallecitos series and the soilat

126 the Burro site in the Murrieta series (https://casoilresource.lawr.ucdavis.edu/gmap/). The Burro

127 prescribed fire took place on May 23, 2018 and burned $0.6 \mathrm{~km}^{2}$. The Tenaja wildfire took place

128 from Sept 4, 2019 through Sept 14, 2019 and burned $7.8 \mathrm{~km}^{2}$. Both sites were located in

129 grasslands dominated by invasive annual grasses from the genus Bromus.

131 Sampling Methods: Three replicated transects were established, with plots 5m outside the burn

132 line (A), and inside the burn line $5 \mathrm{~m}(\mathrm{~B}), 20 \mathrm{~m}$ (C), 100m (D) and 200m (E) (Fig. 1). Transects

133 were established based on proximity to contiguous habitat opposite from the burn section

134 outlined by a firebreak. All lines were set up to be as far as possible from the access road, to

135 cover as much area of the burn unit as possible, and to represent varying distances from the burn

136 edge that might be of relevance to plants and microbes dispersing in from unburned edges. The

137 design was initially established to test the effects of time since fire and distance from burned 
edge on recovery of bacterial, fungal and plant communities post-fire to pre-fire. However, we observed no effect of distance from burned edge and dropped that variable from the analyses presented here. For the Tenaja fire, we added an additional 2 unburned plots in between the three transects for a total of 5 unburned plots and 12 burned plots. Therefore, we had 15 plots within

142 the Burro prescribed fire burn unit and 17 within the Tenaja wildfire burn scar. were collected on 6-2-2018 at 2 weeks post-fire ( $1^{\text {st }}$ post-fire), on 11-28-2018 at 6 months post145 fire (Nov), and on 5-6-2019 at 12 months post-fire (May). The wildfire soils were sampled on $146 \quad 11-5-2019$ at 2 months post-fire ( $1^{\text {st }}$ post fire), on 11-19-2019 at 2.5 months post-fire (Nov), and on 5-13-2020 at 7 months post-fire (May). The first time point captured the immediate effects of

148 fire on the soil microbial community. Unfortunately, due to access constraints for the wildfire,

149 this time frame differs between both burn units. The remaining two sampling points paralleled 150 growing season phenology to account for the effects of intra-seasonal variation in precipitation 151 on soil communities.

At every time point, for each plot, three $\sim 5 \mathrm{~cm}$ deep subsamples $(8 \mathrm{~cm}$ diameter and $10 \mathrm{~cm}$ 153 deep releasable bulb planter filled half depth) were collected haphazardly from the $1 \mathrm{~m}^{2}$ plot and 154 combined for a single homogenized sample per plot. Between plots gloves and soil corers were 155 sterilized with $70 \%$ ethanol. All soils were stored on ice in the field and stored in $-80^{\circ} \mathrm{C}$ freezer 156 that night. A total of 45 soil samples were collected for the prescribed fire ( 3 transects $x 5$ plots $\mathrm{x}$ 1573 time points) and 51 soil samples were collected for the wildfire ( 3 transects x 5 plots +2

158 additional unburned plots $\mathrm{x} 3$ time points). At the first post-fire sampling, the amount of bare 159 ground, rock, litter, char material and live plant cover was estimated for each $1 \mathrm{~m}^{2}$ plot. Litter was identified as any plant growth from previous growing seasons that had not decomposed, and char 
161 material was identified as any ash or blacked charred residue present on the ground surface post

162 fire. We used initial char as a proxy for fire severity as these post-fire residues may mediate

163 nutrient pulses associated with fire and can be linked to fire severity (Neary et al. 1999). In

164 spring of the first post-fire year, the plant community composition was visually estimated in each

165 plot. The cover of each species was estimated such that percent cover could be over 100 to

166 capture species cover in the overlapping layers. Observers used reference squares of known

167 percentages to help estimate cover and increase consistency across different observers.

169 Soil Chemistry. Soil from 32 soil samples from the first post-fire sampling were selected for

170 nutrient analysis, which consisted of 15 samples from 2 weeks post-fire for prescribed fire and

17117 samples at 2 months post-fire for the wildfire as this provided the best temporal comparison

172 between the two sites (i.e. the closest sampling after the fire). Soils were air-dried in a fume

173 hood, and sent to A\&L Western Laboratories, Inc. (Modesto, CA, USA) for analysis

174 (http://www.al-labs-west.com/fee-schedule.php?section=Soil\%20Analysis; soil test suite S1B)

175 including ppm of sulfur $(\mathrm{S})$, potassium $(\mathrm{K})$, magnesium $(\mathrm{Mg})$, calcium $(\mathrm{Ca})$, and sodium $(\mathrm{Na})$,

176 soil $\mathrm{pH}$, cation exchange capacity (CEC), hydrogen concentration, organic matter $(\mathrm{OM})$ in

177 lbs/acre, and phosphorous (weak Bray and Sodium Bicarbonate-P; ppm). To minimize

178 redundancy in some of the soil variables, we dropped variables that were estimates of similar

179 pools (e.g. weak Bray and sodium bicarbonate -P) and variables with strong correlations that

180 indicated similar dynamics (e.g. both $\mathrm{Mg}$ and $\mathrm{Ca}$ were strongly correlated with $\mathrm{CEC}$ at $\mathrm{r}>0.8$,

181 therefore just CEC was kept). This reduced our soil variables to OM, phosphorous (Sodium

182 Bicarbonate-P; ppm), soil pH, K, Na, CEC, and S. These seven variables were analyzed in a

183 principal components analysis to get two axes that described the soil attributes of the sites. The 
184 first axis, which captured $30.74 \%$ of the variation, described plots with high soil $\mathrm{pH}, \mathrm{P}$, and $\mathrm{K}$

185 availability at negative values of PC1 but high Na values at positive values of PC1. The second

186 axis, which captured $26.96 \%$ of variation, described plots across a CEC, S, and OM gradient

187 where negative values indicated plots with high CEC and positive values plots with low CEC

188 (Fig. S1).

189

DNA extractions, PCRs, and Illumina MiSeq sequencing: To identify microbial biomass,

191 richness, and composition, DNA was extracted from 0.25g soil using Qiagen DNeasy PowerSoil

192 Kits following the manufacturer's protocol and stored at $-20^{\circ} \mathrm{C}$ for subsequent analysis.

193 Extracted DNA was amplified using the primer pair ITS4-fun and 5.8s (Taylor et al. 2016) to

194 amplify the ITS2 region of the Internal Transcribed Spacer (ITS), which is the internationally

195 recognized barcode for fungi (Schoch et al. 2012), and the primer pair 515F-806R to amplify the

196 V4 region of the 16S rRNA gene for archaea and bacteria (Caporaso et al. 2012) using the Dual-

197 Index Sequencing Strategy (DIP) (Kozich et al. 2013). Although the 515F-806R amplifies both

198 archaea and bacteria, from here on we say only bacteria for simplicity since bacterial reads were

199 so dominant (Fig. S2). We conducted polymerase chain reaction (PCR) in two steps, each with

$20025 \mu 1$ aliquots. The first PCR amplified gene-specific primers, and the second PCR ligated the

201 DIP barcodes for Illumina sequencing with detailed methods in Methods S1. We sequenced with

202 Illumina MiSeq 2x300bp at the University of California-Riverside Institute for Integrative

203 Genome Biology. Sequences were submitted to the National Center for Biotechnology

204 Information Sequence Read Archive under BioProject PRJNA761493. 
Bacterial and fungal biomass: For all soil samples, bacterial and fungal biomass as a proxy of abundance were estimated by qPCR copy number. Bacterial biomass was estimated based on bacterial 16S rRNA genes using the Eub338/Eub518 primer set (Fierer et al. 2005) and fungal biomass was estimated based on fungal 18S rRNA genes using the FungiQuant-F and FungiQuant-R primer set (Liu et al. 2012). See Methods S2 for methodological details.

212 Bioinformatics. All Illumina MiSeq data were processed using Version 2019.10 of QIIME2

213 pipeline (Bolyen et al. 2019). Forward and reverse adaptors were removed with the cutadapt

214 trim-pair function, and reads were denoised, trimmed to remove low quality regions, and forward

215 and reverse reads were merged using the dada2 denoise-paired functions. Bacterial reads were

216 then tested against the Silva 132 16S classifier (Quast et al. 2013) and fungal reads against the

217 UNITE classifier (Köljalg et al. 2005). For fungi, all reads not identified to Kingdom Fungi were

218 removed, and for bacteria, all mitochondrial and chloroplast genes were removed.

220 Statistical Analysis: All statistical analyses were conducted in R version 4.0.2 (R Core Team

221 2017). To evaluate the plant community response to the prescribed burn (Burro) and wildfire

222 (Tenaja), we ran mixed effects model for species richness, Shannon's diversity, and cover of the

223 exotic and native plant community as a function of burned (burned, unburned) and fire

224 (prescribed, wildfire). Sampling plot was nested within transect as a random effect.

225 To evaluate microbial community responses to the two different fires, we ran mixed effect

226 models on bacterial and fungal richness and abundance (as estimated by copy number) separately

227 for each fire as a function of initial char, or the char measured at the first time-point following

228 fire, time and their interaction. Since we assume that initial char measurements are most 
229 representative of fire severity for the plants and microbes, we analyze all effects as a function of

230 initial char cover. Bacterial and fungal richness were estimated as observed species number after

231 rarefying all samples to same sequencing depth (21,921 for bacteria, 6,338 for fungi) to account

232 for uneven sequencing depth. We included sampling plot as a random effect and specified an

233 autoregressive correlation structure to account for the lack of independence of samples over time.

234 We compared differences among levels by least square means using the "emmeans" package in

$235 \mathrm{R}$ (Lenth et al. 2020). Bacterial and fungal abundance were natural log transformed to meet

236 assumptions of normality for data analysis.

237 To assess recovery of the microbial communities to the fires, we first calculated a Bray-

238 Curtis dissimilarity matrix for the bacterial and fungal communities after rarefaction. For each

239 fire, we used this distance matrix as the response variable in a PERMANOVA (permutational

240 multivariate analysis of variance) with fire (burned/unburned), time, and their interaction as

241 predictor variables. We visualized these differences using a nonmetric multidimensional scaling

242 (NMDS) plot. We also compared the dispersion of the microbial communities between burned

243 and unburned sites for each fire. These analyses were done using the "vegan" package in R

244 (Oksanen et al. 2012).

245 We took a model fitting approach to relate soil properties and plant community attributes

246 to bacterial and fungal communities. We began with a global model that included initial char

247 estimates, soil PCA1 and PCA2, and exotic plant diversity and cover as fixed effects, and

248 transect as a random effect. For the plant community attributes, we selected exotic plant diversity

249 and cover after adjusting for correlations among various community attributes such as richness,

250 cover, and diversity of the total community, native species and exotic species. These models

251 were therefore run with just the May timepoint data for bacterial, fungal, and plant communities. 
252 We conducted stepwise model selection and selected the model with the lowest AIC. We also

253 repeated this analysis with AMF richness as the response variable. The model fitting was done

254 using the "MuMIn" package (Barton 2020). Given that the AMF community may be more

255 sensitive to native plants, we conducted an additional analysis where we ran a mixed effects

256 model for AMF richness as a native plant diversity and fire (prescribed, wildfire). Sampling plot

257 was nested within transect as a random effect.

259 Results:

260 Summary description of fire severity: The burned plots within the prescribed burn site were

261 covered on average by $44 \%$ char and still had on average $35 \%$ cover of intact litter. The burned

262 plots within the wildfire site had on average $74 \%$ char cover and no litter was present. In

263 contrast, litter in unburned plots made up about 78\% of the plot cover in the first post fire

264 sampling in the prescribed burn site and about 77\% cover in the wildfire site. By the spring peak

265 growing season sampling, char was no longer observed in the prescribed burn burned plots and

266 was on average $10 \%$ in the wildfire burned plots.

268 Summary description of site plants: We observed 65 unique plant species within the prescribed

269 burn site and 41 within the wildfire site with an average species richness of $13 \mathrm{species} / \mathrm{m}^{2}$ within

270 the prescribed and 8 species $/ \mathrm{m}^{2}$ at the wildfire site. The most dominant species in the wildfire

271 site regardless of fire treatment were exotic annual grasses, mainly Bromus diandrus and Avena

272 fatua; these species made up on average 64\% cover in the unburned plots and $49 \%$ in burned

273 plots. In the prescribed burn, there was a greater number of dominant species. In the unburned

274 plots, the dominant species were exotic annual grasses (B. hordeacous, Festuca myuros, $F$. 
275 perennis) and the native forb, Calandrinia menziesii; these species ranged in cover from $13 \%$ to

$27623 \%$ cover. In the prescribed fire burned plots, the dominant species each ranged in cover from

$2779 \%$ to $18 \%$ cover and consisted of the exotic grass (F. myuros), exotic forbs (Erodium botrys and

278 E. cicutarium), and native forbs (Calandrinia menziesii, Deinandra fasciculata). Stipa pulchra,

279 the native perennial bunchgrass that is a focal species for management at the Preserve, averaged

$280 \sim 1 \%$ cover at both sites and was absent in the prescribed fire unburned plots.

281

282 Summary description of site soil bacteria and fungi: Overall, we identified 6,338 fungal and

28321,921 bacterial Amplicon Sequence Variants (ASVs), which are similar to operational

284 taxonomic units (OTUs), and approximate microbial species (Glassman \& Martiny 2018). After

285 rarefaction, there were 6,602 bacterial and 1,991 fungal ASVs in the prescribed burn and 3,884

286 bacterial and 1,995 fungal ASVs in the wildfire site at the first time point post-fire, but 6,705

287 bacterial and 1,948 fungal ASVs were observed in the prescribed burn and 3,699 bacterial and

288 1,439 fungal ASVs were observed in the wildfire site in the May following the fire. Mean

289 bacterial and fungal richness and abundance were both higher in prescribed burn than wildfire

290 (Table S2). The prescribed burn and wildfire plots were both dominated by the bacterial phyla

291 Proteobacteria and Actinobacteria, followed by Acidobacteria, Bacteroidetes, Verrucomicrobia,

292 Chloroflexi, Planctomycetes, Gemmatimonadetes, and Cyanobacteria (Fig. S3). Fungi were

293 always dominated by the phylum Ascomycota regardless of site, followed by Basidiomycota,

294 then Glomeromycota (Fig. S4), with larger turnover from unburned to burned at the family level

295 (Fig. S5).

296 
Effect of prescribed versus wildfire on exotic and native plant species richness, diversity, and

298

299

300

301

302

303

304

305

306

307

308

309

310

311

312

313

314

315

316

317

318

319

cover: Exotic plant species richness and Shannon diversity were greater in the prescribed than

wildfire site (richness: $F_{1,27.3}=7.79, p<0.01$, Fig. 2A; div: $F_{1,16.6}=17.05, p<0.001$;) and did not differ between the burned and unburned plots. Both the prescribed fire and wildfires reduced exotic species cover, which was greater in the unburned plots $\left(\mathrm{F}_{1,28}=4.15, \mathrm{p}=0.05\right)$, but did not vary between the two fire sites $\left(F_{1,28}=0.60, p=0.44\right.$, Fig. 2B $)$. Native species richness, diversity, and cover were all greater in the prescribed fire site compared to wildfire site and were not affected by burning (Table S3; Fig. 2).

Effect of prescribed versus wildfire on soil bacterial and fungal richness: Within the prescribed fire, bacterial richness was not influenced by the initial char but did vary over the three sampling points $\left(\right.$ Char $F_{1,13}=0.39, p=0.54$; Time $F_{2,26}=3.5$, $p<0.05$; Fig. 3A), where bacterial richness decreased significantly between Nov and May but did not vary among the other time points (post hoc Nov-May $\mathrm{p}<0.05)$. Within the wildfire, bacterial richness was similarly not affected by char but did vary over time, with richness being the greatest in Nov and not differing between the $1^{\text {st }}$ post-fire sampling and May $\left(\right.$ Char $F_{1,29}=0.17, p=0.69$; Time $F_{2,29}=7.3, p<0.01$; post hoc $1^{\text {st }}-$ Nov p $<0.05$; Nov-May $p<0.01$; Fig. 3B). Fungal richness was not impacted by the prescribed fire such that it did not vary with initial char or over time $\left(\right.$ Char $F_{1,13}=0.15, p=0.7$; Time $F_{2,26}=0.11$, $\mathrm{p}=0.89$; Fig. 3C). Within the wildfire, fungal richness decreased with increasing initial char (Char $\left.F_{1,29}=22.4, p<0.001\right)$ and gradually decreased over time $\left(F_{2,29}=16.4, p<0.001\right.$, Fig. 3D $)$. 
prescribed fire, the relationship between bacterial abundance and initial char tended to shift

321 depending on the sampling point (Char $x$ Time $F_{2,26}=2.86, p=0.08$; Fig. 4A). For instance, there

322 was no relationship between abundance and char at the first post-fire sampling, but it shifted to

323 positive in November (i.e. abundance increased with char) and then negative in spring.

324 Conversely in the wildfire, bacterial richness slightly decreased with increasing char (Char

$325 \mathrm{~F}_{2,29}=7.8, \mathrm{p}<0.01$, Fig. 4B). Bacterial abundance did increase in the wildfire over the sampling

326 periods (Time $\mathrm{F}_{2,29}=29.1, \mathrm{p}<0.0001$; post hoc at $\mathrm{p}<0.051^{\text {st }}$ Post fire $=$ Nov $<$ May). Fungal

327 abundance also varied with initial char depending on the sampling point within the prescribed

328 burn (Char $\mathrm{x}$ Time $\mathrm{F}_{2,26}=5.88, \mathrm{p}<0.01$; Fig. 4C). For the first sampling post-fire, fungal

329 abundance increased with increasing char but for the subsequent two sampling periods the

330 relationship was negative. Within the wildfire, fungal abundance showed a similar trend to

331 bacterial abundance with a small decrease with increasing char (Char $F_{2,2}=6.3, p<0.02$, Fig. 4D).

332 While the relationship between char and fungal abundance did not change with time, average

333 fungal abundance tended to decrease from the initial post-fire sampling point to May (Time

$334 \mathrm{~F}_{2,29}=6.04, \mathrm{p}<0.01$; post hoc at $\mathrm{p}<0.051^{\text {st }}$ Post fire $=$ Nov $<$ May $)$.

337 composition differed to the same degree between burned and unburned plots in both the

338 prescribed burn (PERMANOVA: $\mathrm{F}_{1,39}=1.45, \mathrm{p}<0.05, \mathrm{R}^{2}=0.03$; Fig. 5A) and wildfire $\left(\mathrm{F}_{1,45}=\right.$

$3391.46, \mathrm{p}<0.05, \mathrm{R}^{2}=0.03$; Fig. 5B) but not over time (PERMANOVA: prescribed-Time $\mathrm{F}_{2,39}=$

$3401.23, \mathrm{p}=0.07, \mathrm{R}^{2}=0.06$; wildfire-Time $\left.\mathrm{F}_{2,45}=1.07, \mathrm{p}=0.26, \mathrm{R}^{2}=0.04\right)$. Fungal composition varied

341 between burned and unburned plots both in the prescribed burn (PERMANOVA: $\mathrm{F}_{1,39}=1.82$,

$342 \mathrm{p}<0.01, \mathrm{R}^{2}=0.04$; Fig. 5B) and wildfire $\left(\mathrm{F}_{1,45}=2.39, \mathrm{p}<0.01, \mathrm{R}^{2}=0.05\right.$; Fig. 5C), with slightly 
343 more compositional change in the wildfire than prescribed fire. Similar to bacteria, fungal

344 composition did not vary over the three sampling periods in either fire (PERMANOVA:

345 prescribed: $\mathrm{F}_{2,39}=1.06, \mathrm{p}=0.34, \mathrm{R}^{2}=0.05$; wildfire: $\left.\mathrm{F}_{2,45}=1.05, \mathrm{p}=0.35, \mathrm{R}^{2}=0.04\right)$. The variation in

346 community composition differed between the burned and unburned plots for fungal communities

347 in both fires (prescribed, $\mathrm{p}<0.05$, wildfire, $\mathrm{p}<0.001$ ) but not for bacterial communities

348 (prescribed, $\mathrm{p}=0.27$, wildfire, $\mathrm{p}=0.70$ ).

350 Predictors of bacterial and fungal richness in Spring: Bacterial and fungal richness were

351 predicted by different soil properties at each site (Fig. 6). Within the prescribed burn, bacterial

352 and fungal richness increased with decreasing cation exchange capacity (CEC) and organic

353 matter (OM) (Fig. 6 A, B, blue dots). Bacterial richness was also influenced by the plant

354 community such that it increased with increasing exotic plant richness. For the wildfire, bacterial

355 and fungal richness both responded to PCA1 but in different directions. Bacterial richness

356 decreased as soil $\mathrm{pH}$ and phosphorus concentrations decreased (Fig. 6A, red dots); however

357 fungal richness increased as soil $\mathrm{pH}$ and phosphorus concentrations decreased (Fig. 6B, red

358 dots). AMF richness on its own was not related to soil properties or to the exotic plant

359 community in either fire (Fig 6C). AMF richness followed similar patterns to native plant

360 richness in that the prescribed site $(31 \pm 5)$ had higher AMF richness than the wildfire site

$361\left(17.3 \pm 4.3 ;\right.$ Fire, $\left.\mathrm{F}_{1,26}=9.76, \mathrm{p}<0.01\right)$. While AMF richness was not related to exotic plant

362 diversity, it was marginally related to native plant diversity within the wildfire, such that AMF

363 richness increased with increased native plant diversity (Fire $x$ Native $F_{1,27}=3.14, p=0.09$; Fig.

$3647)$. 


\section{Discussion:}

Wildfire had stronger impacts than prescribed fire on microbial communities and both

368 fires had similar impacts on plants. Both fire types significantly reduced the amount of exotic

369 plant cover but neither reduced exotic plant richness (Q1). Regardless of fire type, having a

370 higher cover and diversity of native plants prior to the fire always resulted in higher cover and

371 diversity of native plants post-fire. Soil microbial richness was differentially impacted by fire.

372 Specifically, fungal richness decreased with increasing char levels only within the wildfire but

373 bacterial richness was not impacted by either fire. Bacterial and fungal biomass were impacted

374 by char levels within both the wildfire and prescribed burn (Q2). Both prescribed fire and

375 wildfire significantly altered bacterial and fungal composition, but fungal composition was more

376 altered by wildfire than prescribed fire (Q3). The factors that predicted bacterial, fungal, and

377 AMF richness at the peak of the growing season differed between the two fires (Q4). In the

378 prescribed burn, bacterial and fungal richness was predicted by soil cation exchange capacity and

379 organic matter (PCA2), and bacterial richness was additionally predicted by exotic plant

380 diversity. In the wildfire, bacterial and fungal richness was not related to the plant community

381 but were predicted by soil $\mathrm{pH}$ and phosphorus concentrations (PCA1). AMF richness was not

382 related to soil attributes or the exotic plant community but was related to native plant diversity.

383 Prescribed fire is often used as a tool to reduce exotic abundance and recover native plant

384 species in grasslands (Menke 1992; Dyer 2002; DiTomaso et al. 2006). Here, both fires reduced

385 exotic plant cover but neither recovered native plant cover or richness, recapitulating the findings

386 of a recent meta-analysis that neither prescribed burns nor wildfires resulted in increased native

387 plant performance (Alba et al. 2015). Appropriately timed fires may reduce viable seeds of

388 exotic plants and allow establishment of native species from the seedbank (Meyer \& Schiffman 
1999), which not exist. In the prescribed fire site, native forbs like Deinandra fasciculata slightly increased in cover in the burned plots. Overall, the prescribed burn site, which has a long history

391 of management, did possess a higher richness and diversity of native species suggesting that

392 periodic fire may be maintaining the integrity of the native seedbank. Yet, in both cases, exotic

393 plant species were more abundant than native, suggesting that regular burning may not

394 necessarily alter the abundance of exotics but may ameliorate the long-term impacts of invasion.

395 For example, long-term plant invasions can erode native seedbanks, reducing the natural

396 colonization of native plant species after management interventions (Cox \& Allen 2008).

397 However, a more robust study that directly evaluates seedbank composition across a history of

398 management would provide more insights into this process.

399 Fires generally have a larger negative impact on fungal than bacterial richness (Pressler,

400 Moore \& Cotrufo 2019). Although we know of no similar studies in grasslands, a study in

401 Chinese pine forests found that bacterial richness was not altered by fires of low-, medium-, or

402 high- severity (Li et al. 2019). We similarly found that bacterial richness was not impacted by

403 either fire, which is likely due to the high resilience of bacteria that has been detected in forested

404 ecosystems (Xiang et al. 2014) and of ammonia oxidizing bacteria in grasslands (Docherty et al.

405 2012). In our study, fungal richness tended to increase in the prescribed fire sites but decreased

406 by $13-17 \%$ in the wildfire site. A study of fungal community composition along a boreal

407 coniferous forest fire chronosequence ranging from 2 to 152 years found that fungal richness and

408 diversity was higher at the most recently burned forest sites, whereas the 152 year old site had

409 low diversity and evenness (Sun et al. 2015). Thus, it is possible that prescribed fires that are less

410 severe can increase heterogeneity and thereby increase fungal richness as occurs with plants

\section{1 (Agee 1998).}


413 than prescribed fire and that fire had stronger impacts on fungi than bacteria are largely in line

414 with the literature (Dooley \& Treseder 2012; Pressler, Moore \& Cotrufo 2019), but there are

415 some key differences. Fire impacts on soil communities are the result of a variety of factors

416 including soil temperature and the inputs associated with post-fire residues such as ash and char

417 (Neary et al. 1999). Grassland fires typically are lower severity due to low fuels and quick

418 moving fires and are thus thought to have small impacts on the soil microbial community

419 (Dooley \& Treseder 2012). For example, a study examining effects of prescribed fires of varying

420 fire intensity on Northern Great Plain grasslands found no effect of fire on microbial biomass, as

421 measured by PLFA (Reinhart, Dangi \& Vermeire 2016), and a meta-analysis of fire effects on

422 biomass found that microbial biomass declined after fires in boreal and temperate forests but not

423 after grassland fires (Dooley \& Treseder 2012). Yet, in this case, we were able to detect

424 significant reductions of bacterial and fungal biomass following grassland wildfires. Within both

425 fires fungal and bacterial biomass were sensitive to the amount of char present immediately after

426 the fire. The ability of our study to detect reductions in microbial biomass could be due to our

427 rapid post-fire sampling, usage of char percentage as an index of soil burn severity, which is not

428 typically measured, or because we used an estimate of microbial biomass with higher sensitivity.

429 The prescribed burn resulted in greater heterogeneity in soil microbial community

430 responses. We observed increased dispersion in fungal composition following the prescribed fire

431 in comparison to the wildfire, which is likely due to the greater variation in remaining litter and

432 char levels in the prescribed fire than the wildfire. Due to our time-series sampling, we observed

433 that the impact of fire on bacterial and fungal abundance tended to fluctuate more over the

434 growing season in the prescribed fire than wildfire site. This may be due to the higher diversity 
435 of native plants in the prescribed fire sites or it may be due to the increased heterogeneity after

436 the prescribed fire, since wildfires tend to be more homogenizing (Turner et al. 1994).

437 Both the prescribed fire and wildfire had small but significant impacts on both bacterial

438 and fungal composition. Wildfire had a slightly larger impact on fungal composition than

439 prescribed fire whereas the prescribed fire and wildfire similarly affected bacterial composition,

440 which is likely due to the higher resilience of bacteria to fires (Ferrenberg et al. 2013; Xiang et

441 al. 2014). There is limited literature for comparison since only $12 \%$ of post-fire microbiome

442 studies occur in grasslands. Most studies examine biomass alone (Pressler, Moore \& Cotrufo

443 2019) or arbuscular mycorrhizal colonization and spore counts and not the total fungal

444 community (Cairney \& Bastias 2007). However, a recent study investigating the impacts of

445 experimental fire in a California grassland found that fire altered bacterial composition but not

446 alpha diversity (Yang et al. 2019), similar to our study. Another recent study of prescribed fires

447 in Mediterranean Aleppo pine forests found that higher severity prescribed fires had larger

448 impacts on bacterial composition than lower severity ones, although both significantly altered

449 bacterial composition (Lucas-Borja et al. 2019). Thus, prescribed fires are more likely to alter

450 microbial composition than richness, which could nonetheless alter plant growth and

451 composition (van der Heijden et al. 1998).

452 Primary plant colonizers can dictate the initial microbial community that will

453 subsequently mediate plant recovery (Kardol, Bezemer \& van der Putten 2006; Cheeke et al.

454 2019). In the wildfire site with lower overall plant diversity, microbial communities were not

455 sensitive to the aboveground exotic plant community. While we were unable to track the

456 complete recovery of native plant communities in this study, we did find that at the peak of the

457 first post-fire growing season, native plant diversity was positively correlated to AMF richness in 
458 the wildfire site. The fact that this positive relationship between AMF richness and native plant

459 richness was not detected in the more biodiverse prescribed fire is corroborated by the fact that

460 the benefit of AMF richness on plant richness tends to saturate after 12-14 AMF species (van der

461 Heijden et al. 1998).

462 Some of the prevalent exotic species present at this site (Avena and Bromus spp) have

463 exerted strong priority effects on microbial composition in other grasslands within the state

464 (Hausmann \& Hawkes 2009; Hausmann \& Hawkes 2010), suggesting that relationships between

465 the microbial community and exotic species may become more apparent over time. The low

466 plant diversity of invaded annual grasslands paired with their high productive fine root systems

467 that increase soil organic matter may contribute to lower variation in soil communities

468 (Steenwerth et al. 2002), which we observed in the fungal communities of the unburned plots at

469 both sites. Within the prescribed burn that has a history of regularly timed burns, we found that

470 bacterial and fungal richness was sensitive to increasing organic matter, in addition to CEC, and

471 also to soil pH, which is supported by the literature (Fierer \& Jackson 2006; Glassman, Wang \&

472 Bruns 2017). This site also had greater native plant richness and diversity, potentially increasing

473 the resistance of the AMF community to fire by buffering some of the degradation of mutualistic

474 fungi that can occur with plant invasion (Callaway et al. 2008). These findings further suggest

475 that soil legacies associated with long-term invasions may alter the responsiveness of soil

476 microbial communities to the aboveground plant communities.

477 Unexpected wildfires may provide opportunistic management windows to re-establish

478 native species in degraded grasslands; however, the success of these efforts are contingent on

479 mediating some of the recovery constraints associated with long-term invasion (Larios \& Suding

480 2013). While our findings support the idea that consistent management actions such as periodic 
481 prescribed burns may promote native plant diversity (Steenwerth et al. 2002), they do not

482 indicate that periodic burns or wildfires will increase native plant performance or cover without

483 intervention. Soil inoculations are likely required to recover native soil microbial and plant

484 diversity in these situations (Aprahamian et al. 2016; Emam 2016; Balshor et al. 2017), and

485 these strategies are more likely to be successful if local soil inocula are used (Maltz \& Treseder

486 2015) since mycorrhizal partnerships tend to be context dependent (Klironomos 2003). Thus, the

487 success of an opportunistic management action capitalizing on a wildfire would be contingent on

488 addressing invader legacies (e.g. adding seeds, soil amendments) and implementing periodic

489 management actions (e.g. prescribed fires) to regularly clear out persistent plant invaders.

490 Acknowledgements: We thank Hailey Laskey, Carole Bell, and Zachary Principe for allowing

491 us access to the Santa Rosa Ecological Plateau Reserve, and Judy Chung, Lachland Charles,

492 Miguel Solis and Soren Weber for aid in field work and plant data collection.

493 Authors' Contributions: SIG conceived of the field experiment with joint project

494 development and experimental design by SIG and LL. JC, JWJR, LL, SIG, SSS conducted

495 field work. JWJR performed molecular work and JC and KEW assisted in bacterial biomass

496 measurements. JC, JWJR, MFPC, and SIG conducted bioinformatics. JWJR, LL, and SIG

497 conducted statistical analyses and made the figures. SIG and LL wrote the first draft. All

498 authors contributed edits to the manuscript and approved the final submission. 
502 Figure 1. Map of study site with both fire perimeters displayed (A) and insets show the sampling

503 transects within the Tenaja wildfire (B) and Burro prescribed burn (C). Samples were collected

$5045 \mathrm{~m}$ outside the burn (blue), and 5m, 20m, 100m, and 200m (red) within the burn. Two additional

505 unburned samples were sampled between transects within the Tenaja wildfire.

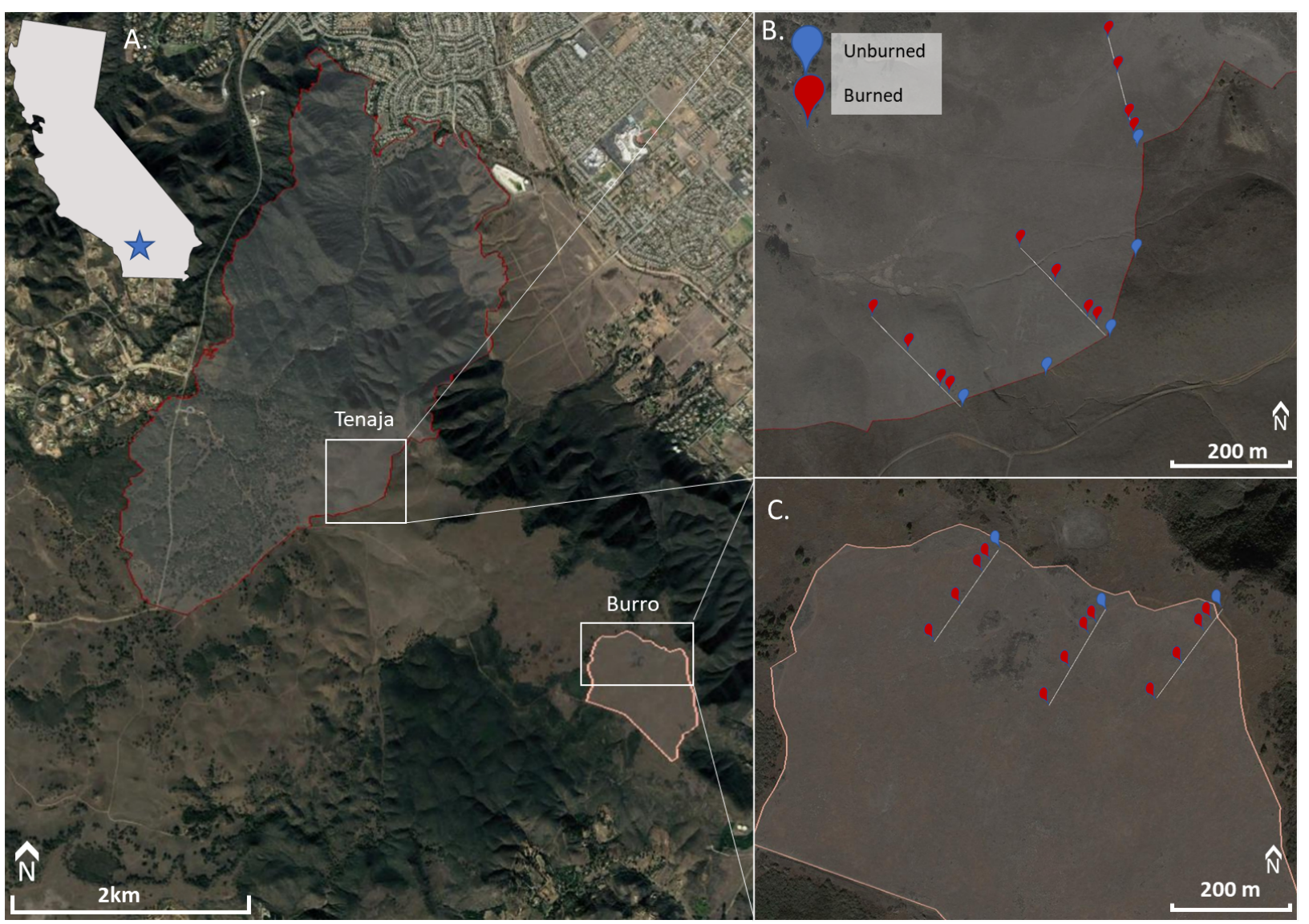


513 Figure 2. Plant community metrics of species richness (A) and percent cover (B) for native and 514 exotic species in burned and unburned plots within the Burro prescribed burn and Tenaja wildfire

515 sites. Segments and letters indicate significant differences between Burro and Tenaja at $\mathrm{p}<0.05$.

516 Pairwise letters denote the significant effect of burning on exotic species cover at $\mathrm{p}<0.05$.
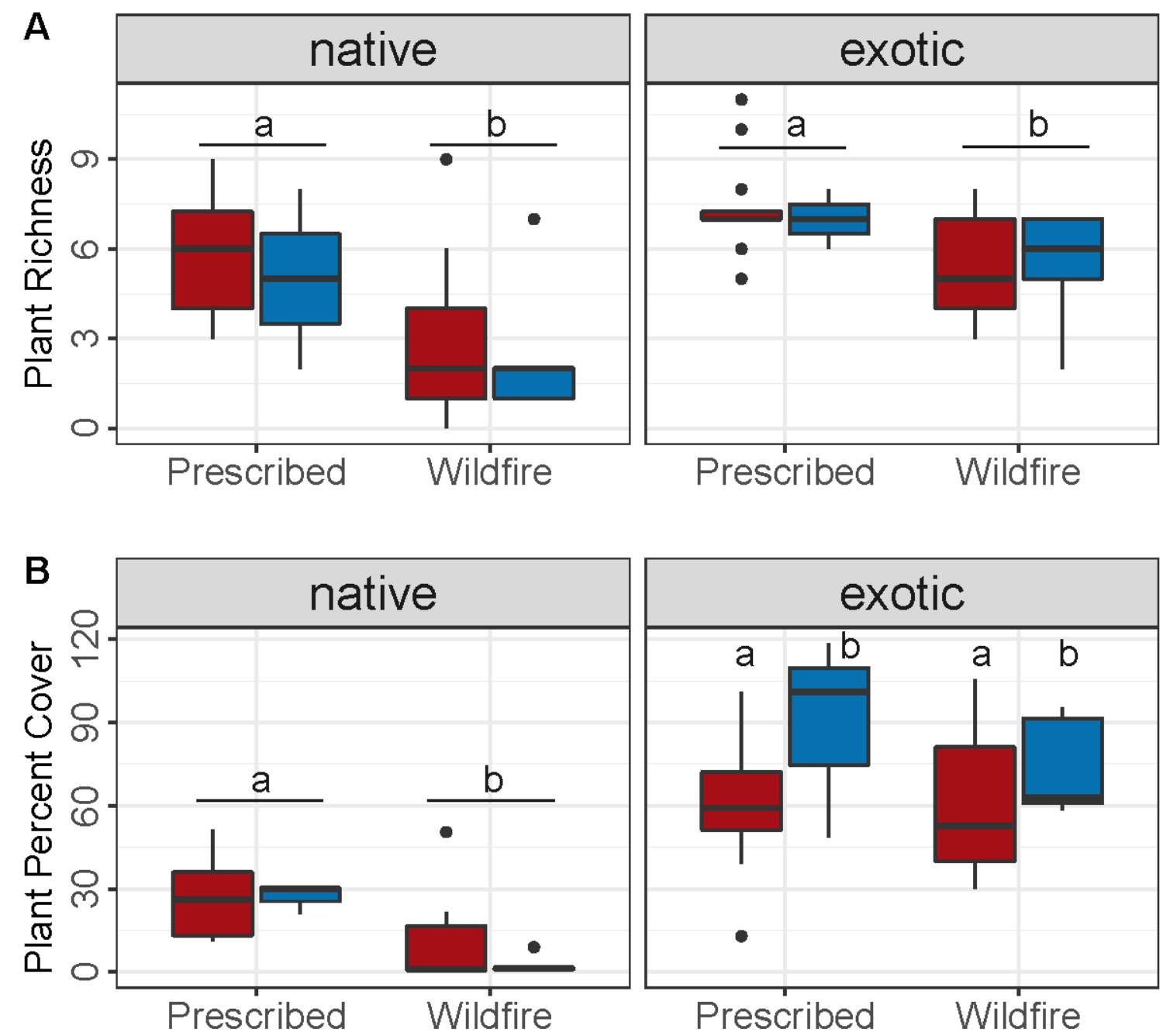
521 Figure 3. Bacterial and fungal richness for both Burro prescribed fire and Tenaja wildfire over

522 time in burned and unburned plots. Segments and letters indicate post-hoc differences for the

523 main effect of time at $\mathrm{p}<0.05$.

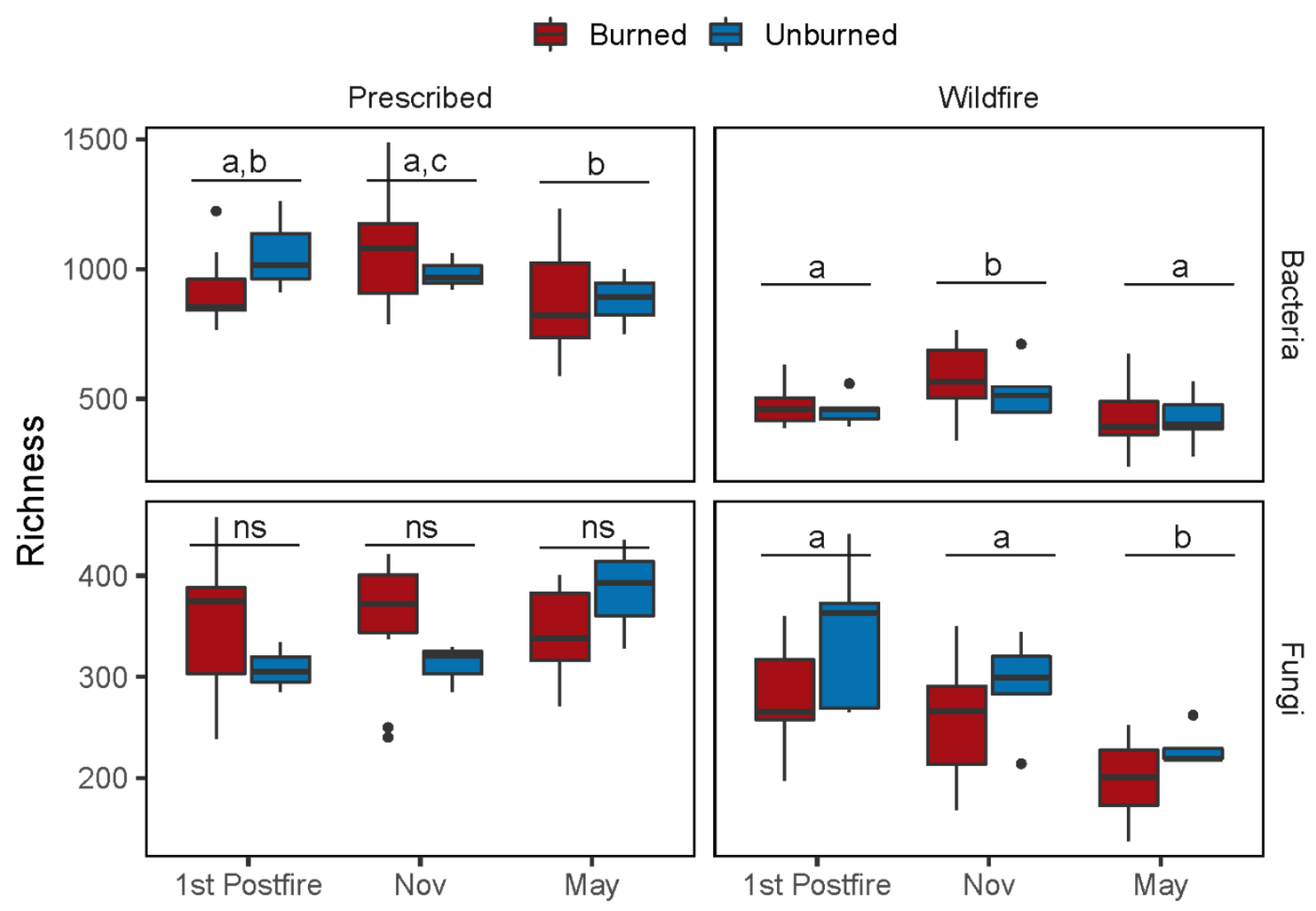


532 Figure 4. Bacterial abundance, estimated as 16S copy number, at the A) Burro prescribed fire

533 and the B) Tenaja wildfire. Fungal abundance, estimated as $18 \mathrm{~S}$ copy number, at the C) Burro

534 prescribed fire and the D) Tenaja wildfire. Lines represent significant relationships for either

535 main effect of char on abundance or two-way interactions of Char and Time.

\section{A Prescribed}
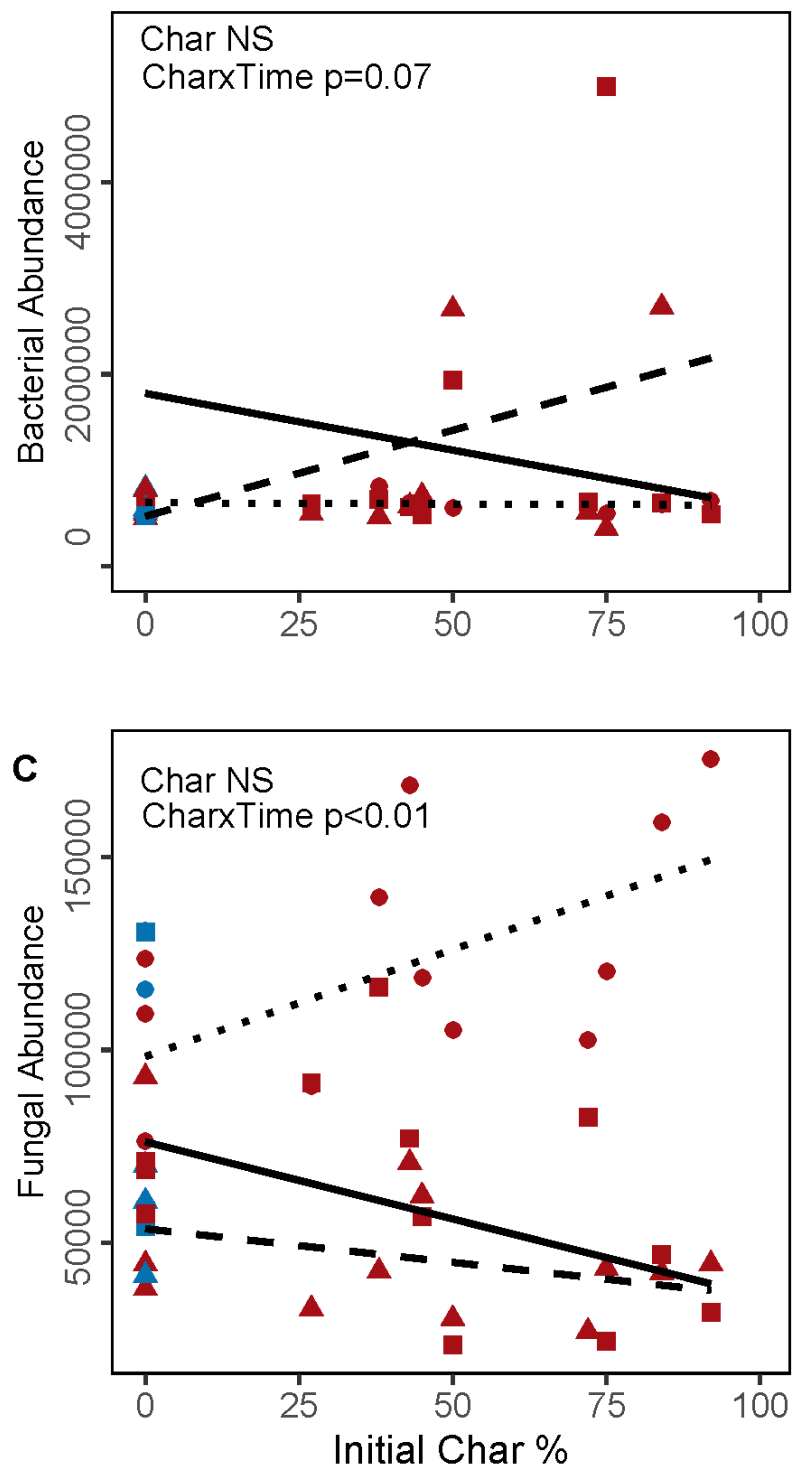

536
B Wildfire
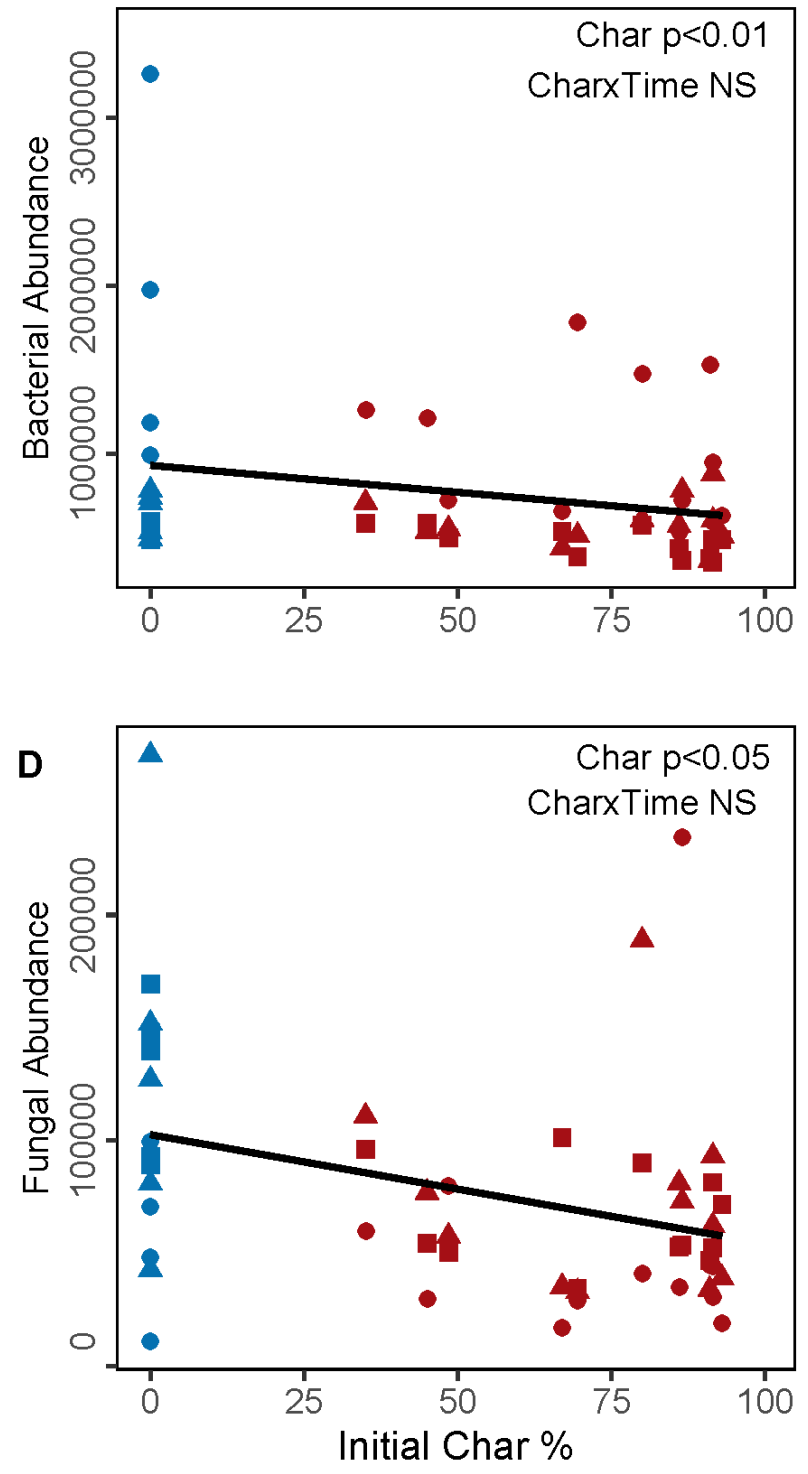

Fire $\quad$ Burned Unburned 
537 Figure 5. Nonmetric Multidimensional Scaling ordination of burned versus unburned soil

538 microbial composition for bacteria and fungi in the Burro prescribed fire versus Tenaja wildfire 539 at the three time points.

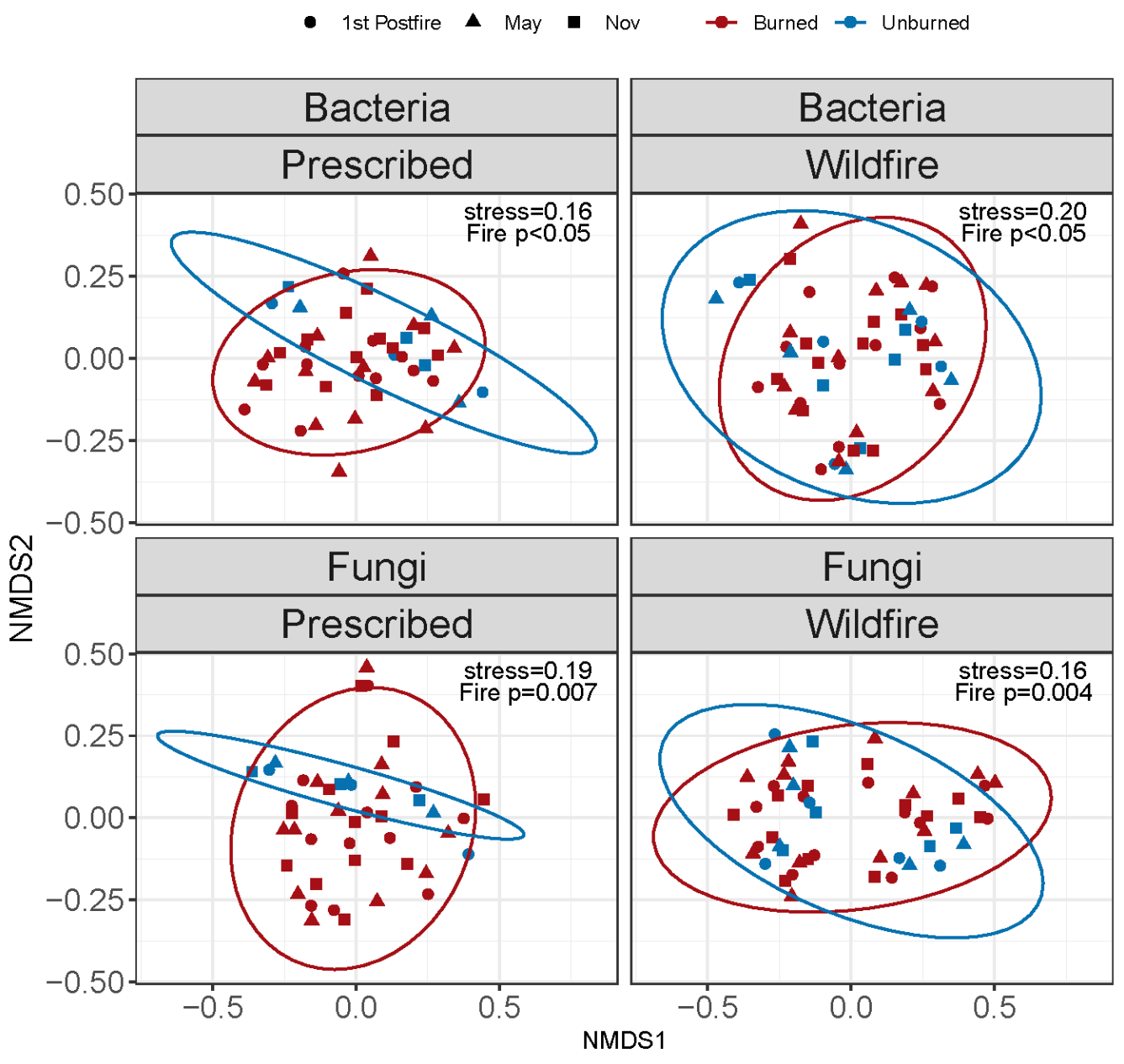

541 
547 Figure 6. Best fit model parameter coefficients for relating soil variables (PCA1, PCA2) and

548 plant community diversity (exotic Shannon diversity) to richness of A) bacteria B) fungi and C)

549 arbuscular mycorrhizal fungi (AMF) for the Tenaja wildfire versus the Burro prescribed fire.

550 Error bars not overlapping 0 indicate significant parameters in model. Note: the best fit models

551 often contained parameters that were not significant.

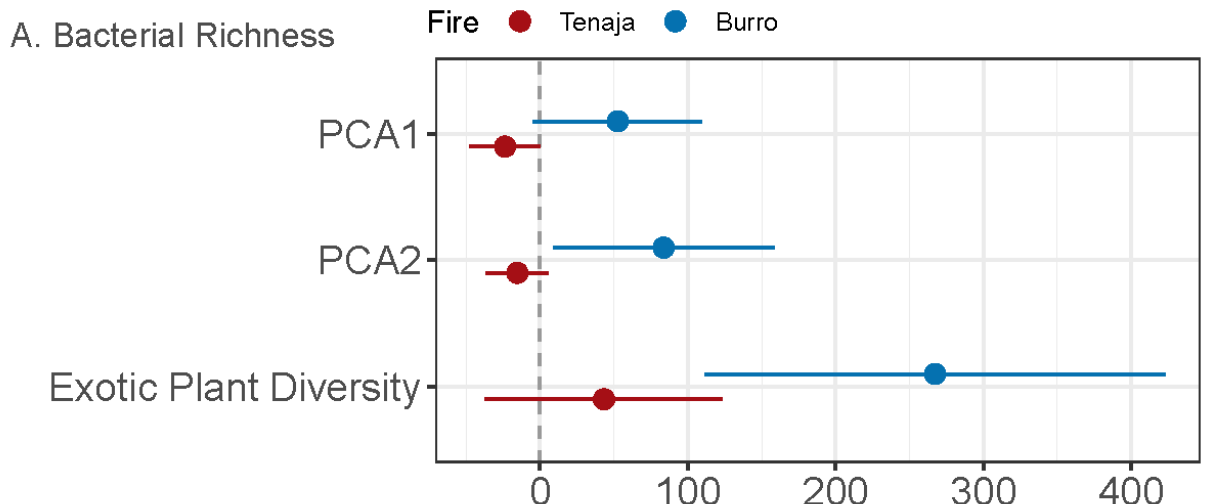

B. Fungal Richness

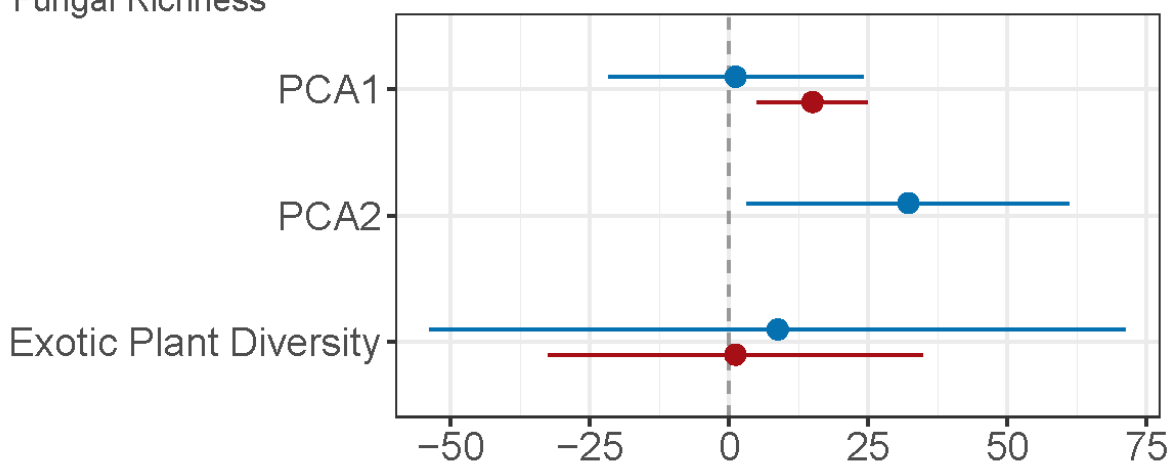

C. AMF Richness

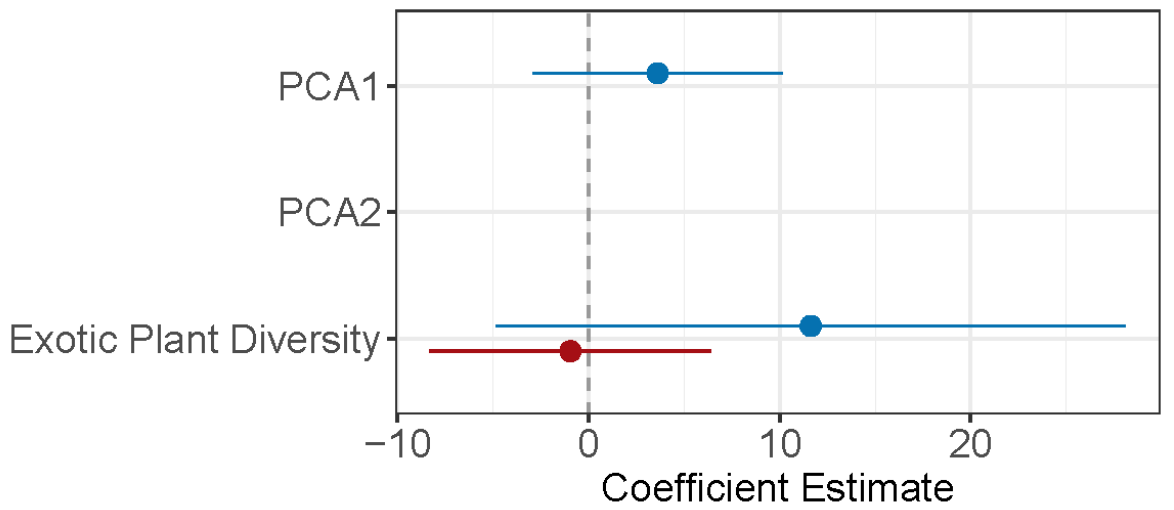


554 Figure 7. Native plant diversity increases with AMF richness in Tenaja but not Burro fire.

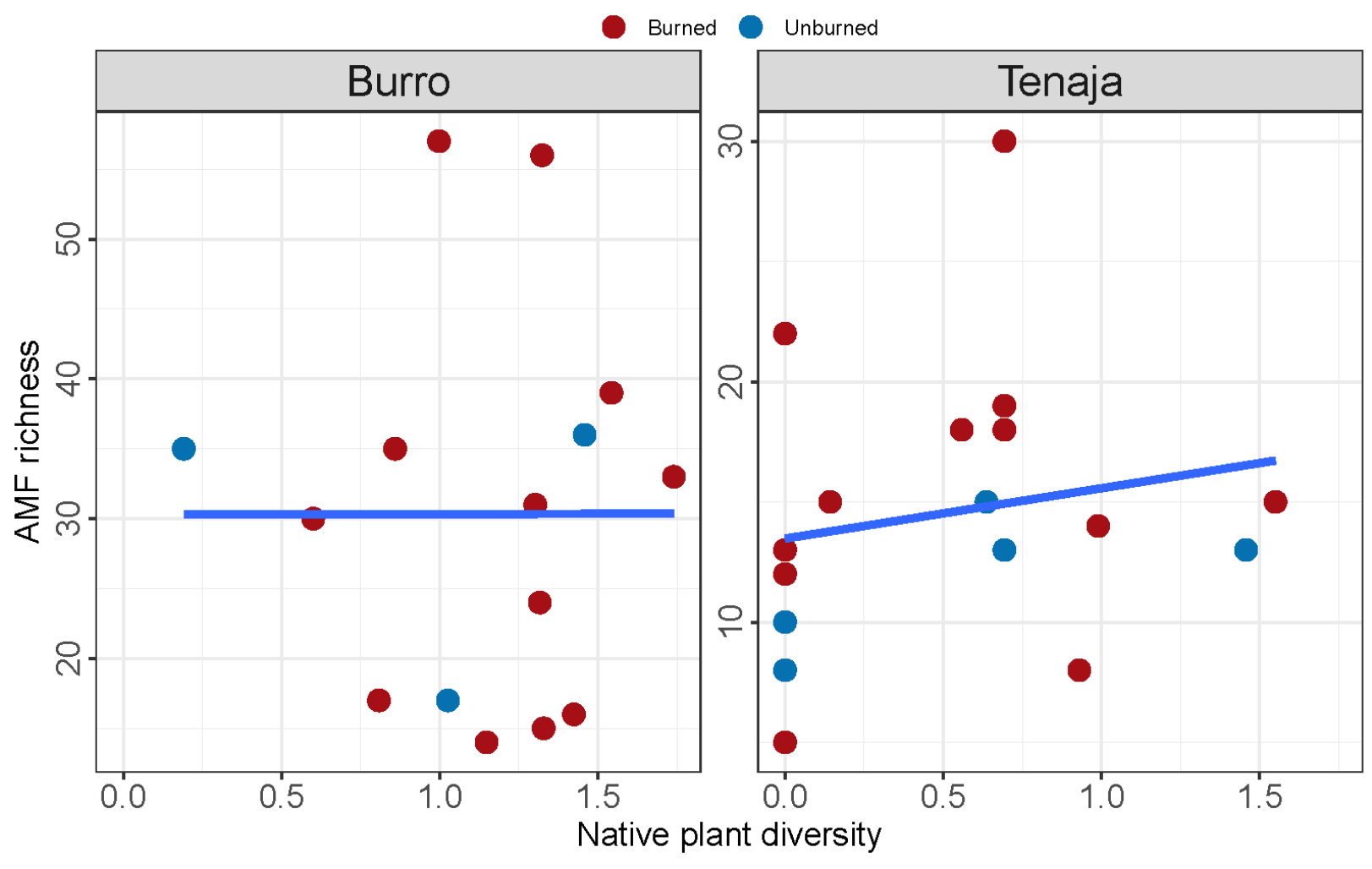




\section{References}

Agee, J.K. (1998) Fire and pine ecosystems. Ecology and biogeography of Pinus, 193-218.

Alba, C., Skalova, H., McGregor, K.F., D'Antonio, C. \& Pysek, P. (2015) Native and exotic plant species respond differently to wildfire and prescribed fire as revealed by meta-analysis. Journal of Vegetation Science, 26, 102-113.

Aprahamian, A.M., Lulow, M.E., Major, M.R., Balazs, K.R., Treseder, K.K. \& Maltz, M.R. (2016) Arbuscular mycorrhizal inoculation in coastal sage scrub restoration. Botany, 94, 493499.

Balshor, B.J., Garrambone, M.S., Austin, P., Balazs, K.R., Weihe, C., Martiny, J.B.H., Huxman, T.E., McCollum, J.R. \& Kimball, S. (2017) The effect of soil inoculants on seed germination of native and invasive species. Botany, 95, 469-480.

Barton, K. (2020) MuMIn: Multi-Model Inference. R package version 1.43.17.

Blackburn, T.C. \& Anderson, K. (1993) Before the wilderness: environmental management by native Californians. Ballena Press, Menlo Park, CA.

Bolyen, E., Rideout, J.R., Dillon, M.R., Bokulich, N., Abnet, C.C., Al-Ghalith, G.A., Alexander, H., Alm, E.J., Arumugam, M., Asnicar, F., Bai, Y., Bisanz, J.E., Bittinger, K., Brejnrod, A., Brislawn, C.J., Brown, C.T., Callahan, B.J., Caraballo-Rodriguez, A.M., Chase, J., Cope, E.K., Da Silva, R., Diener, C., Dorrestein, P.C., Douglas, G.M., Durall, D.M., Duvallet, C., Edwardson, C.F., Ernst, M., Estaki, M., Fouquier, J., Gauglitz, J.M., Gibbons, S.M., Gibson, D.L., Gonzalez, A., Gorlick, K., Guo, J.R., Hillmann, B., Holmes, S., Holste, H., Huttenhower, C., Huttley, G.A., Janssen, S., Jarmusch, A.K., Jiang, L.J., Kaehler, B.D., Bin Kang, K., Keefe, C.R., Keim, P., Kelley, S.T., Knights, D., Koester, I., Kosciolek, T., Kreps, J., Langille, M.G.I., Lee, J., Ley, R., Liu, Y.X., Loftfield, E., Lozupone, C., Maher, M., Marotz, C., Martin, B.D., McDonald, D., Mclver, L.J., Melnik, A.V., Metcalf, J.L., Morgan, S.C., Morton, J.T., Naimey, A.T., Navas-Molina, J.A., Nothias, L.F., Orchanian, S.B., Pearson, T., Peoples, S.L., Petras, D., Preuss, M.L., Pruesse, E., Rasmussen, L.B., Rivers, A., Robeson, M.S., Rosenthal, P., Segata, N., Shaffer, M., Shiffer, A., Sinha, R., Song, S.J., Spear, J.R., Swafford, A.D., Thompson, L.R., Torres, P.J., Trinh, P., Tripathi, A., Turnbaugh, P.J., UIHasan, S., vander Hooft, J.J.J., Vargas, F., Vazquez-Baeza, Y., Vogtmann, E., von Hippel, M., Walters, W., Wan, Y.H., Wang, M.X., Warren, J., Weber, K.C., Williamson, C.H.D., Willis, A.D., Xu, Z.Z., Zaneveld, J.R., Zhang, Y.L., Zhu, Q.Y., Knight, R. \& Caporaso, J.G. (2019) Reproducible, interactive, scalable and extensible microbiome data science using QIIME 2. Nature Biotechnology, 37, 852-857.

Brundrett, M.C. \& Tedersoo, L. (2018) Evolutionary history of mycorrhizal symbioses and global host plant diversity. New Phytologist, 220, 1108-1115.

Cairney, J.W.G. \& Bastias, B.A. (2007) Influences of fire on forest soil fungal communities. Canadian Journal of Forest Research-Revue Canadienne De Recherche Forestiere, 37, 207-215.

Callaway, R.M., Cipollini, D., Barto, K., Thelen, G.C., Hallett, S.G., Prati, D., Stinson, K. \& Klironomos, J. (2008) Novel weapons: Invasive plant suppresses fungal mutualists in America but not in its native Europe. Ecology, 89, 1043-1055. 
Callaway, R.M., Thelen, G.C., Rodriguez, A. \& Holben, W.E. (2004) Soil biota and exotic plant invasion. Nature, 427, 731-733.

Caporaso, J.G., Lauber, C.L., Walters, W.A., Berg-Lyons, D., Huntley, J., Fierer, N., Owens, S.M., Betley, J., Fraser, L., Bauer, M., Gormley, N., Gilbert, J.A., Smith, G. \& Knight, R. (2012) Ultra-high-throughput microbial community analysis on the Illumina HiSeq and MiSeq platforms. Isme Journal, 6, 1621-1624.

Cheeke, T.E., Zheng, C.Y., Koziol, L., Gurholt, C.R. \& Bever, J.D. (2019) Sensitivity to AMF species is greater in late-successional than early-successional native or nonnative grassland plants. Ecology, 100.

Corbin, J.D. \& D'Antonio, C.M. (2010) Not novel, just better: competition between native and non-native plants in California grasslands that share species traits. Plant Ecology, 209, 71-81.

Cox, R.D. \& Allen, E.B. (2008) Composition of soil seed banks in southern California coastal sage scrub and adjacent exotic grassland. Plant Ecology, 198, 37-46.

Crowther, T.W., van den Hoogen, J., Wan, J., Mayes, M.A., Keiser, A.D., Mo, L., Averill, C. \& Maynard, D.S. (2019) The global soil community and its influence on biogeochemistry. Science, 365, 772-+.

D’Antonio, C., Bainbridge, S., Kennedy, C., Bartolome, J.W. \& Reynolds, S. (2002) Ecology and Restoration of California Grasslands with special emphasis on the

influence of fire and grazing on native grassland species.

DiTomaso, J.M., Brooks, M.L., Allen, E.B., Minnich, R., Rice, P.M. \& Kyser, G.B. (2006) Control of invasive weeds with prescribed burning. Weed Technology, 20, 535-548.

Docherty, K.M., Balser, T.C., Bohannan, B.J.M. \& Gutknecht, J.L.M. (2012) Soil microbial responses to fire and interacting global change factors in a California annual grassland. Biogeochemistry, 109, 63-83.

Dooley, S.R. \& Treseder, K.K. (2012) The effect of fire on microbial biomass: a meta-analysis of field studies. Biogeochemistry, 109, 49-61.

Dove, N.C. \& Hart, S.C. (2017) Fire reduces fungal species richness and in situ mycorrhizal colonization: a meta-analysis. Fire Ecology, 13, 37-65.

Dyer, A.R. (2002) Burning and grazing management in a California grassland: Effect on bunchgrass seed viability. Restoration Ecology, 10, 107-111.

Emam, T. (2016) Local soil, but not commercial AMF inoculum, increases native and non-native grass growth at a mine restoration site. Restoration Ecology, 24, 35-44.

Eppinga, M.B., Rietkerk, M., Dekker, S.C., De Ruiter, P.C. \& Van der Putten, W.H. (2006) Accumulation of local pathogens: a new hypothesis to explain exotic plant invasions. Oikos, 114, 168-176.

Eviner, V.T. \& Hawkes, C.V. (2008) Embracing Variability in the Application of Plant-Soil Interactions to the Restoration of Communities and Ecosystems. Restoration Ecology, 16, 713-729.

Ferrenberg, S., O'Neill, S.P., Knelman, J.E., Todd, B., Duggan, S., Bradley, D., Robinson, T., Schmidt, S.K., Townsend, A.R., Williams, M.W., Cleveland, C.C., Melbourne, B.A., Jiang, L. \& Nemergut, D.R. (2013) Changes in assembly processes in soil bacterial communities following a wildfire disturbance. Isme Journal, 7, 1102-1111. 
Fierer, N., Jackson, J.A., Vilgalys, R. \& Jackson, R.B. (2005) Assessment of soil microbial community structure by use of taxon-specific quantitative PCR assays. Applied and Environmental Microbiology, 71, 4117-4120.

Fierer, N. \& Jackson, R.B. (2006) The diversity and biogeography of soil bacterial communities. Proceedings of the National Academy of Sciences of the United States of America, 103, 626-631.

Fryer, J.L. \& Luensmann, P.S. (2012) Fire regimes of the conterminous United States. Fire Effects Information System (FEIS). U.S. Department of Agriculture, Forest Service, Rocky Mountain Research Station, Fire Sciences Laboratory, Missoula, MT.

Garbaye, J. (1994) Helper bacteria- new dimension to the mycorrhizal symbiosis. New Phytologist, 128, 197-210.

Glassman, S.I. \& Martiny, J.B.H. (2018) Broadscale Ecological Patterns Are Robust to Use of Exact Sequence Variants versus Operational Taxonomic Units. mSphere, 3.

Glassman, S.I., Wang, I.J. \& Bruns, T.D. (2017) Environmental filtering by pH and soil nutrients drives community assembly in fungi at fine spatial scales. Molecular Ecology, 26, 69606973.

Hausmann, N.T. \& Hawkes, C.V. (2009) Plant neighborhood control of arbuscular mycorrhizal community composition. New Phytologist, 183, 1188-1200.

Hausmann, N.T. \& Hawkes, C.V. (2010) Order of plant host establishment alters the composition of arbuscular mycorrhizal communities. Ecology, 91, 2333-2343.

Hawkes, C.V., Belnap, J., D'Antonio, C. \& Firestone, M.K. (2006) Arbuscular mycorrhizal assemblages in native plant roots change in the presence of invasive exotic grasses. Plant and Soil, 281, 369-380.

Hawkes, C.V., Wren, I.F., Herman, D.J. \& Firestone, M.K. (2005) Plant invasion alters nitrogen cycling by modifying the soil nitrifying community. Ecology Letters, 8, 976-985.

Holden, S.R., Rogers, B.M., Treseder, K.K. \& Randerson, J.T. (2016) Fire severity influences the response of soil microbes to a boreal forest fire. Environmental Research Letters, 11.

Holmes, T.H. \& Rice, K.J. (1996) Patterns of growth and soil-water utilization in some exotic annuals and native perennial bunchgrasses of California. Annals of Botany, 78, 233-243.

Kardol, P., Bezemer, T.M. \& van der Putten, W.H. (2006) Temporal variation in plant-soil feedback controls succession. Ecology Letters, 9, 1080-1088.

Klironomos, J.N. (2003) Variation in plant response to native and exotic arbuscular mycorrhizal fungi. Ecology, 84, 2292-2301.

Knapp, E.E., Estes, B.L. \& Skinner, C.N. (2009) Ecological Effects of Prescribed Fire Season: A Literature Review and Synthesis for Managers General Technical Report No. PSW-GTR224

. (ed. U.F. Service). Pacific Southwest Research Station.

Köljalg, U., Larsson, K.H., Abarenkov, K., Nilsson, R.H., Alexander, I.J., Eberhardt, U., Erland, S., Hoiland, K., Kjoller, R., Larsson, E., Pennanen, T., Sen, R., Taylor, A.F.S., Tedersoo, L., Vralstad, T. \& Ursing, B.M. (2005) UNITE: a database providing web-based methods for the molecular identification of ectomycorrhizal fungi. New Phytologist, 166, 1063-1068.

Kozich, J.J., Westcott, S.L., Baxter, N.T., Highlander, S.K. \& Schloss, P.D. (2013) Development of a Dual-Index Sequencing Strategy and Curation Pipeline for Analyzing Amplicon Sequence 
Data on the MiSeq Illumina Sequencing Platform. Applied and Environmental Microbiology, 79, 5112-5120.

Kulmatiski, A., Beard, K.H., Stevens, J.R. \& Cobbold, S.M. (2008) Plant-soil feedbacks: a metaanalytical review. Ecology Letters, 11, 980-992.

Lankau, R.A., Bauer, J.T., Anderson, M.R. \& Anderson, R.C. (2014) Long-term legacies and partial recovery of mycorrhizal communities after invasive plant removal. Biological Invasions, 16, 1979-1990.

Larios, L. \& Suding, K.N. (2013) Restoration Within Protected Areas: When and How to Intervene to Manage Plant Invasions? Plant Invasions in Protected Areas: Patterns, Problems and Challenges (eds L.C. Foxcroft, P. Pysek, D.M. Richardson \& P. Genovesi), pp. 599-618.

Lenth, R.V., Buerkner, P., Herve, M., Love, J., Riebl, H. \& Singmann, H. (2020) emmeans: Estimated Marginal Means, aka Least-Squares Means.

Leys, B.A., Marlon, J.R., Umbanhowar, C. \& Vanniere, B. (2018) Global fire history of grassland biomes. Ecology and Evolution, 8, 8831-8852.

Li, W.K., Niu, S.K., Liu, X.D. \& Wang, J.M. (2019) Short-term response of the soil bacterial community to differing wildfire severity in Pinus tabulaeformis stands. Scientific Reports, 9.

Liu, C.M., Kachur, S., Dwan, M.G., Abraham, A.G., Aziz, M., Hsueh, P.R., Huang, Y.T., Busch, J.D., Lamit, L.J., Gehring, C.A., Keim, P. \& Price, L.B. (2012) FungiQuant: A broad-coverage fungal quantitative real-time PCR assay. Bmc Microbiology, 12.

Lucas-Borja, M.E., Miralles, I., Ortega, R., Plaza-Alvarez, P.A., Gonzalez-Romero, J., Sagra, J., Soriano-Rodriguez, M., Certini, G., Moya, D. \& Heras, J. (2019) Immediate fire-induced changes in soil microbial community composition in an outdoor experimental controlled system. Science of the Total Environment, 696.

Maltz, M.R. \& Treseder, K.K. (2015) Sources of inocula influence mycorrhizal colonization of plants in restoration projects: a meta-analysis. Restoration Ecology, 23, 625-634.

McKemey, M., Ens, E., Rangers, Y.M., Costello, O. \& Reid, N. (2020) Indigenous Knowledge and Seasonal Calendar Inform Adaptive Savanna Burning in Northern Australia. Sustainability, 12.

Menke, J.W. (1992) Grazing and fire management for native perrennial grass restoration in California grasslands. Fremontia, 20, 22-25.

Meyer, M.D. \& Schiffman, P.M. (1999) Fire season and mulch reduction in a California grassland: a comparison of restoration strategies. Madrono, 46, 25-37.

Mummey, D.L. \& Rillig, M.C. (2006) The invasive plant species Centaurea maculosa alters arbuscular mycorrhizal fungal communities in the field. Plant and Soil, 288, 81-90.

Neary, D.G., Klopatek, C.C., DeBano, L.F. \& Ffolliott, P.F. (1999) Fire effects on belowground sustainability: a review and synthesis. Forest Ecology and Management, 122, 51-71.

Oksanen, J., Blanchet, F., Kindt, R., Legendre, P., Minchin, P., O'Hara, R., Simpson, G., Solymos, P., Stevens, M. \& Wagner, H. (2012) vegan: Community Ecology Package. R package version 2.0-10.

Pressler, Y., Moore, J.C. \& Cotrufo, M.F. (2019) Belowground community responses to fire: meta-analysis reveals contrasting responses of soil microorganisms and mesofauna. Oikos, 128, 309-327. 
Pringle, A., Bever, J.D., Gardes, M., Parrent, J.L., Rillig, M.C. \& Klironomos, J.N. (2009) Mycorrhizal Symbioses and Plant Invasions. Annual Review of Ecology Evolution and Systematics, 40, 699-715.

Quast, C., Pruesse, E., Yilmaz, P., Gerken, J., Schweer, T., Yarza, P., Peplies, J. \& Glockner, F.O. (2013) The SILVA ribosomal RNA gene database project: improved data processing and web-based tools. Nucleic Acids Research, 41, D590-D596.

R Core Team (2017) R: A Language and Environment for Statistical Computing. R Foundation for Statistical Computing, Vienna, Austria.

Reinhart, K.O., Dangi, S.R. \& Vermeire, L.T. (2016) The effect of fire intensity, nutrients, soil microbes, and spatial distance on grassland productivity. Plant and Soil, 409, 203-216.

Running, S.W. (2006) Is global warming causing more, larger wildfires? Science, 313, 927-928.

Ryan, K.C., Knapp, E.E. \& Varner, J.M. (2013) Prescribed fire in North American forests and woodlands: history, current practice, and challenges. Frontiers in Ecology and the Environment, 11, E15-E24.

Sandel, B., Corbin, J.D. \& Krupa, M. (2011) Using plant functional traits to guide restoration: A case study in California coastal grassland. Ecosphere, 2.

Schoch, C.L., Seifert, K.A., Huhndorf, S., Robert, V., Spouge, J.L., Levesque, C.A., Chen, W., Bolchacova, E., Voigt, K., Crous, P.W., Miller, A.N., Wingfield, M.J., Aime, M.C., An, K.D., Bai, F.Y., Barreto, R.W., Begerow, D., Bergeron, M.J., Blackwell, M., Boekhout, T., Bogale, M., Boonyuen, N., Burgaz, A.R., Buyck, B., Cai, L., Cai, Q., Cardinali, G., Chaverri, P., Coppins, B.J., Crespo, A., Cubas P, P., Cummings, C., Damm, U., de Beer, Z.W., de Hoog, G.S., Del-Prado, R., Dentinger, B., Dieguez-Uribeondo, J., Divakar, P.K., Douglas, B., Duenas, M., Duong, T.A., Eberhardt, U., Edwards, J.E., Elshahed, M.S., Fliegerova, K., Furtado, M., Garcia, M.A., Ge, Z.W., Griffith, G.W., Griffiths, K., Groenewald, J.Z., Groenewald, M., Grube, M., Gryzenhout, M., Guo, L.D., Hagen, F., Hambleton, S., Hamelin, R.C., Hansen, K., Harrold, P., Heller, G., Herrera, G., Hirayama, K., Hirooka, Y., Ho, H.M., Hoffmann, K., Hofstetter, V., Hognabba, F., Hollingsworth, P.M., Hong, S.B., Hosaka, K., Houbraken, J., Hughes, K., Huhtinen, S., Hyde, K.D., James, T., Johnson, E.M., Johnson, J.E., Johnston, P.R., Jones, E.B., Kelly, L.J., Kirk, P.M., Knapp, D.G., Koljalg, U., Kovacs, G.M., Kurtzman, C.P., Landvik, S., Leavitt, S.D., Liggenstoffer, A.S., Liimatainen, K., Lombard, L., Luangsa-Ard, J.J., Lumbsch, H.T., Maganti, H., Maharachchikumbura, S.S., Martin, M.P., May, T.W., McTaggart, A.R., Methven, A.S., Meyer, W., Moncalvo, J.M., Mongkolsamrit, S., Nagy, L.G., Nilsson, R.H., Niskanen, T., Nyilasi, I., Okada, G., Okane, I., Olariaga, I., Otte, J., Papp, T., Park, D., Petkovits, T., Pino-Bodas, R., Quaedvlieg, W., Raja, H.A., Redecker, D., Rintoul, T., Ruibal, C., Sarmiento-Ramirez, J.M., Schmitt, I., Schussler, A., Shearer, C., Sotome, K., Stefani, F.O., Stenroos, S., Stielow, B., Stockinger, H., Suetrong, S., Suh, S.O., Sung, G.H., Suzuki, M., Tanaka, K., Tedersoo, L., Telleria, M.T., Tretter, E., Untereiner, W.A., Urbina, H., Vagvolgyi, C., Vialle, A., Vu, T.D., Walther, G., Wang, Q.M., Wang, Y., Weir, B.S., Weiss, M., White, M.M., Xu, J., Yahr, R., Yang, Z.L., Yurkov, A., Zamora, J.C., Zhang, N., Zhuang, W.Y., Schindel, D. \& Fungal Barcoding, C. (2012) Nuclear ribosomal internal transcribed spacer (ITS) region as a universal DNA barcode marker for Fungi. Proceedings of the National Academy of Sciences of the United States of America, 109. 
Shade, A., Peter, H., Allison, S.D., Baho, D.L., Berga, M., Burgmann, H., Huber, D.H., Langenheder, S., Lennon, J.T., Martiny, J.B.H., Matulich, K.L., Schmidt, T.M. \& Handelsman, J. (2012) Fundamentals of microbial community resistance and resilience. Frontiers in Microbiology, 3.

Steenwerth, K.L., Jackson, L.E., Calderon, F.J., Stromberg, M.R. \& Scow, K.M. (2002) Soil microbial community composition and land use history in cultivated and grassland ecosystems of coastal California. Soil Biology \& Biochemistry, 34, 1599-1611.

Stephens, S.L. \& Collins, B.M. (2004) Fire regimes of mixed conifer forests in the north-central Sierra Nevada at multiple spatial scales. Northwest Science, 78, 12-23.

Suding, K.N., Harpole, W.S., Fukami, T., Kulmatiski, A., MacDougall, A.S., Stein, C. \& van der Putten, W.H. (2013) Consequences of plant-soil feedbacks in invasion. Journal of Ecology, 101, 298-308.

Sun, H., Santalahti, M., Pumpanen, J., Koster, K., Berninger, F., Raffaello, T., Jumpponen, A., Asiegbu, F.O. \& Heinonsalo, J. (2015) Fungal Community Shifts in Structure and Function across a Boreal Forest Fire Chronosequence. Applied and Environmental Microbiology, 81, 7869-7880.

Taylor, D.L., Walters, W.A., Lennon, N.J., Bochicchio, J., Krohn, A., Caporaso, J.G. \& Pennanen, T. (2016) Accurate Estimation of Fungal Diversity and Abundance through Improved Lineage-Specific Primers Optimized for Illumina Amplicon Sequencing. Applied and Environmental Microbiology, 82, 7217-7226.

Turner, M.G., Hargrove, W.W., Gardner, R.H. \& Romme, W.H. (1994) Effects of fire on landscape heterogeneity in Yellowstone-National Park, Wyoming. Journal of Vegetation Science, 5, 731-742.

Valliere, J.M., Balch, S., Bell, C., Contreras, C. \& Hilbig, B.E. (2019) Repeated mowing to restore remnant native grasslands invaded by nonnative annual grasses: upsides and downsides above and below ground. Restoration Ecology, 27, 261-268.

van der Heijden, M.G.A., Klironomos, J.N., Ursic, M., Moutoglis, P., Streitwolf-Engel, R., Boller, T., Wiemken, A. \& Sanders, I.R. (1998) Mycorrhizal fungal diversity determines plant biodiversity, ecosystem variability and productivity. Nature, 396, 69-72.

van der Heijden, M.G.A., Streitwolf-Engel, R., Riedl, R., Siegrist, S., Neudecker, A., Ineichen, K., Boller, T., Wiemken, A. \& Sanders, I.R. (2006) The mycorrhizal contribution to plant productivity, plant nutrition and soil structure in experimental grassland. New Phytologist, 172, 739-752.

Vogelsang, K.M. \& Bever, J.D. (2009) Mycorrhizal densities decline in association with nonnative plants and contribute to plant invasion. Ecology, 90, 399-407.

Westerling, A.L., Hidalgo, H.G., Cayan, D.R. \& Swetnam, T.W. (2006) Warming and earlier spring increase western US forest wildfire activity. Science, 313, 940-943.

Xiang, X.J., Shi, Y., Yang, J., Kong, J.J., Lin, X.G., Zhang, H.Y., Zeng, J. \& Chu, H.Y. (2014) Rapid recovery of soil bacterial communities after wildfire in a Chinese boreal forest. Scientific Reports, 4.

Yang, S., Zheng, Q., Yang, Y., Yuan, M., Ma, X., Chiariello, N.R., Docherty, K.M., Field, C.B., Gutknecht, J.L.M., Hungate, B.A., Niboyet, A., Roux, X.L. \& Zhou, J. (2019) Fire affects the taxonomic and functional composition of soil microbial communities, with cascading effects on grassland ecosystem functioning. Global Change Biology. 
Yuan, M.T.M., Kakouridis, A., Starr, E., Nguyen, N., Shi, S.J., Pett-Ridge, J., Nuccio, E., Zhou, J.Z. \& Firestone, M. (2021) Fungal-Bacterial Cooccurrence Patterns Differ between Arbuscular Mycorrhizal Fungi and Nonmycorrhizal Fungi across Soil Niches. Mbio, 12.

Zubek, S., Majewska, M.L., Baszkowski, J., Stefanowicz, A.M., Nobis, M. \& Kapusta, P. (2016) Invasive plants affect arbuscular mycorrhizal fungi abundance and species richness as well as the performance of native plants grown in invaded soils. Biology and Fertility of Soils, 52, 879-893. 


\section{Supplementary Information}

Table S1: GPS Coordinates and elevation for the 15 sampling locations established at the initial time point for Burro (May 21, 2018) and the 17 sampling locations of Tenaja (October 29th, 2019)

\begin{tabular}{|l|l|l|c|c|c|l|}
\hline Site & Line & Plot & Date & Elevation $(\mathrm{m})$ & Latitude & Longitude \\
\hline Tenaja & 1 & A & $10 / 29 / 19$ & 559 & 33.540061 & -117.25194 \\
\hline Tenaja & 1 & B & $10 / 29 / 19$ & 560 & 33.540235 & -117.252 \\
\hline Tenaja & 1 & C & $10 / 29 / 19$ & 561 & 33.54031 & -117.25203 \\
\hline Tenaja & 1 & D & $10 / 29 / 19$ & 563 & 33.541077 & -117.25224 \\
\hline Tenaja & 1 & E & $10 / 29 / 19$ & 567 & 33.541936 & -117.25248 \\
\hline Tenaja & 2 & A & $10 / 29 / 19$ & 565 & 33.536947 & -117.25255 \\
\hline Tenaja & 2 & B & $10 / 29 / 19$ & 566 & 33.537064 & -117.25277 \\
\hline Tenaja & 2 & C & $10 / 29 / 19$ & 563 & 33.537103 & -117.2528 \\
\hline Tenaja & 2 & D & $10 / 29 / 19$ & 553 & 33.537698 & -117.25345 \\
\hline Tenaja & 2 & E & $10 / 29 / 19$ & 547 & 33.538304 & -117.25416 \\
\hline Tenaja & 3 & A & $10 / 29 / 19$ & 555 & 33.53585 & -117.25527 \\
\hline Tenaja & 3 & B & $10 / 29 / 19$ & 555 & 33.536004 & -117.25545 \\
\hline Tenaja & 3 & C & $10 / 29 / 19$ & 555 & 33.536093 & -117.25556 \\
\hline Tenaja & 3 & D & $10 / 29 / 19$ & 551 & 33.536601 & -117.25618 \\
\hline Tenaja & 3 & E & $10 / 29 / 19$ & 549 & 33.537199 & -117.25698 \\
\hline Burro & 1 & O & $5 / 21 / 18$ & 592 & 33.526254 & -117.22979 \\
\hline Burro & 1 & A & $5 / 21 / 18$ & 592 & 33.526324 & -117.22973 \\
\hline Burro & 1 & B & $5 / 21 / 18$ & 592 & 33.526215 & -117.22982 \\
\hline Burro & 1 & C & $5 / 21 / 18$ & 592 & 33.526104 & -117.2299 \\
\hline
\end{tabular}




\begin{tabular}{|l|l|l|l|l|l|l|} 
Burro & 1 & E & $5 / 21 / 18$ & 597 & 33.524726 & -117.23095 \\
\hline Burro & 2 & O & $5 / 21 / 18$ & 594 & 33.525167 & -117.22533 \\
\hline Burro & 2 & A & $5 / 21 / 18$ & 594 & 33.525239 & -117.22527 \\
\hline Burro & 2 & B & $5 / 21 / 18$ & 593 & 33.525143 & -117.22536 \\
\hline Burro & 2 & C & $5 / 21 / 18$ & 594 & 33.525041 & -117.22547 \\
\hline Burro & 2 & D & $5 / 21 / 18$ & 595 & 33.524476 & -117.22603 \\
\hline Burro & 2 & E & $5 / 21 / 18$ & 596 & 33.523786 & -117.22668 \\
\hline Burro & 3 & O & $5 / 21 / 18$ & 603 & 33.525204 & -117.22766 \\
\hline Burro & 3 & A & $5 / 21 / 18$ & 602 & 33.52529 & -117.22759 \\
\hline Burro & 3 & B & $5 / 21 / 18$ & 604 & 33.525163 & -117.22768 \\
\hline Burro & 3 & C & $5 / 21 / 18$ & 603 & 33.525043 & -117.22775 \\
\hline Burro & 3 & D & $5 / 21 / 18$ & 604 & 33.524426 & -117.22818 \\
\hline Burro & 3 & E & $5 / 21 / 18$ & 605 & 33.523635 & -117.22871 \\
\hline
\end{tabular}


Table S2. Summary of mean bacterial and fungal richness (observed species number after rarefaction) and abundance (copy number) for the prescribed (Burro) versus wildfire (Tenaja) in burned versus unburned plots in the three post-fire time points.

\begin{tabular}{|l|l|l|r|r|r|r|}
\hline Project & Fire & Timepoint & $\begin{array}{r}\text { Bacterial } \\
\text { richness }\end{array}$ & $\begin{array}{r}\text { Bacterial } \\
\text { abundance } \\
\text { (copy } \\
\text { number) }\end{array}$ & $\begin{array}{c}\text { Fungal } \\
\text { richness }\end{array}$ & $\begin{array}{c}\text { Fungal } \\
\text { abundance } \\
\text { (copy } \\
\text { number) }\end{array}$ \\
\hline Burro & Burned & $\begin{array}{l}\text { 1st } \\
\text { Postfire }\end{array}$ & 907 & 659998 & 353 & 124243 \\
\hline Burro & Burned & Nov & 1081 & 2182566 & 359 & 47548 \\
\hline Burro & Burned & May & 882 & 5596993 & 345 & 62322 \\
\hline Burro & Unburned & $\begin{array}{l}\text { 1st } \\
\text { Postfire }\end{array}$ & 1062 & 637272 & 308 & 101580 \\
\hline Burro & Unburned & Nov & 983 & 659699 & 312 & 57400 \\
\hline Burro & Unburned & May & 881 & 6539746 & 385 & 81059 \\
\hline Tenaja & Burned & $\begin{array}{l}\text { 1st } \\
\text { Postfire }\end{array}$ & 470 & 472323 & 283 & 65579 \\
\hline Tenaja & Burned & Nov & 576 & 588521 & 258 & 73750 \\
\hline Tenaja & Burned & May & 427 & 1007902 & 199 & 55596 \\
\hline Tenaja & Unburned & $\begin{array}{l}\text { 1st } \\
\text { Postfire }\end{array}$ & 460 & 531619 & 342 & 127870 \\
\hline Tenaja & Unburned & Nov & 533 & 650234 & 292 & 134723 \\
\hline Tenaja & Unburned & May & 422 & 1639982 & 229 & 60239 \\
\hline
\end{tabular}


Table S3: Model summary statistics for plant community composition metrics for exotic and native species.

\begin{tabular}{|c|c|c|c|c|c|c|}
\hline \multirow[b]{2}{*}{ Diversity Metric } & \multicolumn{2}{|c|}{ Burn Treatment } & \multicolumn{2}{|c|}{ Fire Site } & \multicolumn{2}{|c|}{ Fire*Burn } \\
\hline & $\mathbf{F}$ & $p$-value & $\mathbf{F}$ & $p$-value & $\mathbf{F}$ & $p$-value \\
\hline Exotic Cover & $4.15_{1,28}$ & 0.05 & $0.60_{1,28}$ & 0.44 & $0.52_{1,28}$ & 0.47 \\
\hline Exotic Diversity & $1.041,15$ & 0.32 & $17.05_{1,16.6}$ & $<0.001$ & $0.39_{1,16.6}$ & 0.54 \\
\hline Exotic Richness & $0.12_{1,27.3}$ & 0.73 & $7.79_{1,27.3}$ & 0.009 & $0.09_{1,27.3}$ & 0.77 \\
\hline Native Cover & $0.26_{1,15}$ & 0.62 & $33.7_{1,16}$ & $<0.001$ & $0.90_{1,16}$ & 0.36 \\
\hline Native Diversity & $0.61_{1,27.3}$ & 0.44 & $7.92_{1,27.3}$ & $<0.01$ & $0.82_{1,27.3}$ & 0.37 \\
\hline Native Richness & $0.241,15$ & 0.63 & $12.34_{1,16}$ & $<0.01$ & $0.19_{1,16}$ & 0.67 \\
\hline
\end{tabular}


Table S4: Model summary statistics for bacterial and fungal richness and abundance for Burro and Tenaja fires. Predictor variables included Initial char cover, time, and their interaction. Plot number was included as a random effect, with an autoregressive correlation structure.

\begin{tabular}{|c|c|c|c|c|c|c|c|c|}
\hline & \multicolumn{4}{|c|}{ Bacterial } & \multicolumn{4}{c|}{ Fungal } \\
\hline & \multicolumn{2}{|c|}{ Richness } & \multicolumn{2}{c|}{ Abundance } & \multicolumn{2}{c|}{ Richness } & \multicolumn{2}{c|}{ Abundance } \\
\hline & $\mathbf{F}$ & $\begin{array}{c}\mathbf{p}- \\
\text { value }\end{array}$ & $\mathbf{F}$ & $\begin{array}{c}\mathbf{p}- \\
\text { value }\end{array}$ & $\mathbf{F}$ & $\begin{array}{c}\mathbf{p}- \\
\text { value }\end{array}$ & $\mathbf{F}$ & $\begin{array}{c}\mathbf{p}- \\
\text { value }\end{array}$ \\
\hline Burro & & & & & & & & \\
\hline Initial Char & $\begin{array}{c}0.39_{1,1} \\
3\end{array}$ & 0.55 & $0.14_{1,13}$ & 0.71 & $0.15_{1,13}$ & 0.70 & $1.49_{1,13}$ & 0.24 \\
\hline Time & $\begin{array}{c}3.50_{2,2} \\
6\end{array}$ & $<0.05$ & $1.71_{2,26}$ & 0.20 & $0.11_{2,26}$ & 0.89 & $29.90_{2,2}$ & $<0.001$ \\
\hline Char*Time & $\begin{array}{c}1.91_{2,2} \\
6\end{array}$ & 0.17 & $2.86_{2,26}$ & 0.08 & $0.97_{2,26}$ & 0.39 & $5.88_{2,26}$ & $<0.01$ \\
\hline Tenaja & & & & & & & & \\
\hline Initial Char & $\begin{array}{c}0.17_{1,2} \\
9\end{array}$ & 0.68 & $7.78_{1,29}$ & $<0.01$ & $22.41_{1,2}$ & $<0.001$ & $6.33_{1,29}$ & $<0.05$ \\
\hline Time & $\begin{array}{c}7.32_{2,2} \\
9\end{array}$ & $<0.01$ & $29.12_{2,2}$ & $<0.001$ & $16.41_{2,2}$ & $<0.001$ & $6.04_{2,29}$ & $<0.01$ \\
\hline Char*Time & $\begin{array}{c}0.18_{2,2} \\
9\end{array}$ & 0.83 & $1.40_{2,29}$ & 0.26 & $0.57_{2,29}$ & 0.57 & $0.96_{2,29}$ & 0.40 \\
\hline
\end{tabular}


Figure S1. Principal component analysis of soil abiotic variables used to describe soil environmental gradient used for analyses. For PC1, increasing values indicate greater sodium $(\mathrm{Na})$ concentrations and lower values indicate higher soil $\mathrm{pH}$, phosphorus (P) and Potassium (K). For PC2 increasing values indicate lower cation exchange capacity (CEC) while negative values indicated plots with high CEC, organic matter (OM) and sulfur (S).

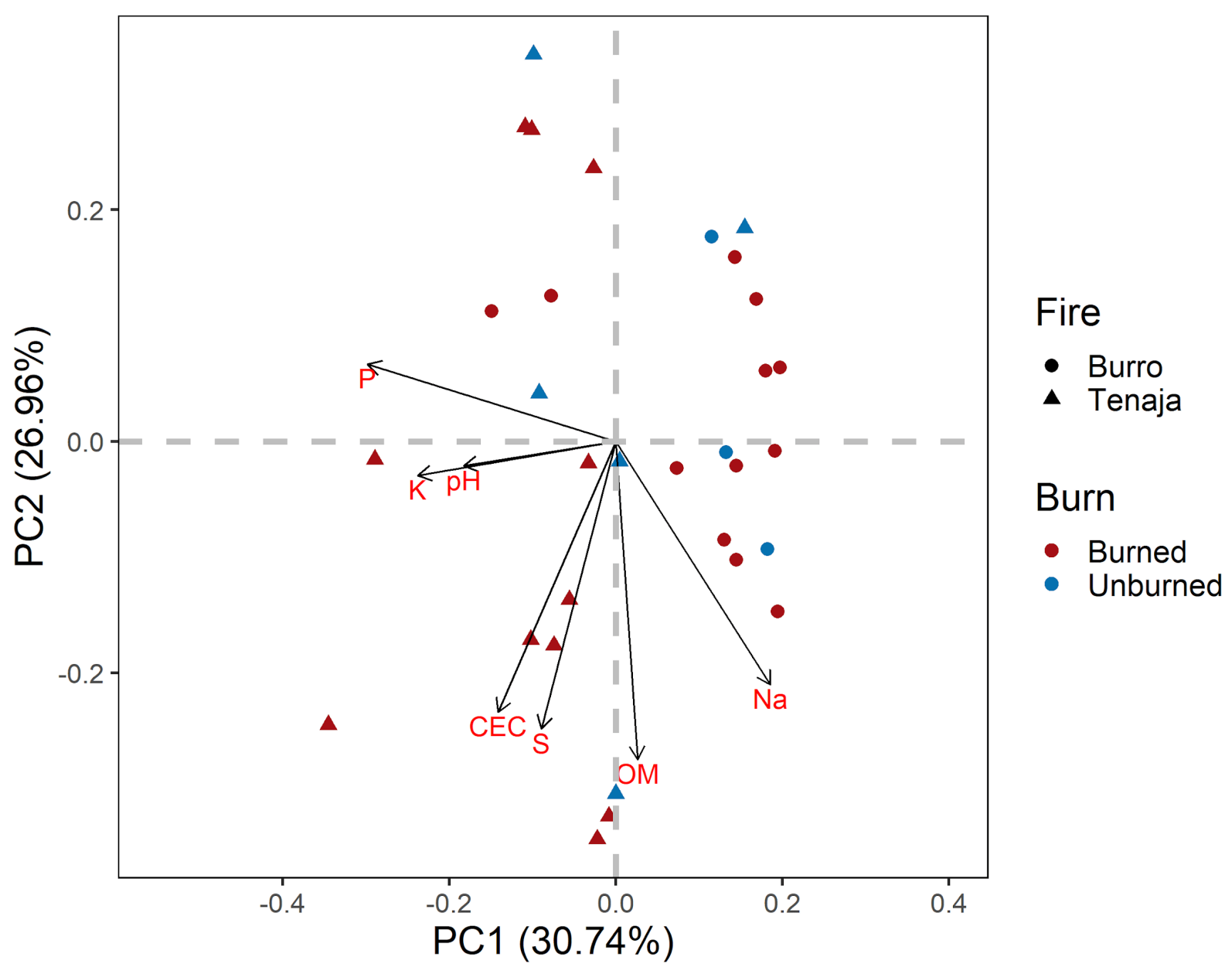


Fig. S2. Relative sequence abundance of archaeal versus bacterial reads in the Burro prescribed fire A) unburned plots and B) burned plots and in the Tenaja wildfire C) unburned and D) burned plots at the three time points.
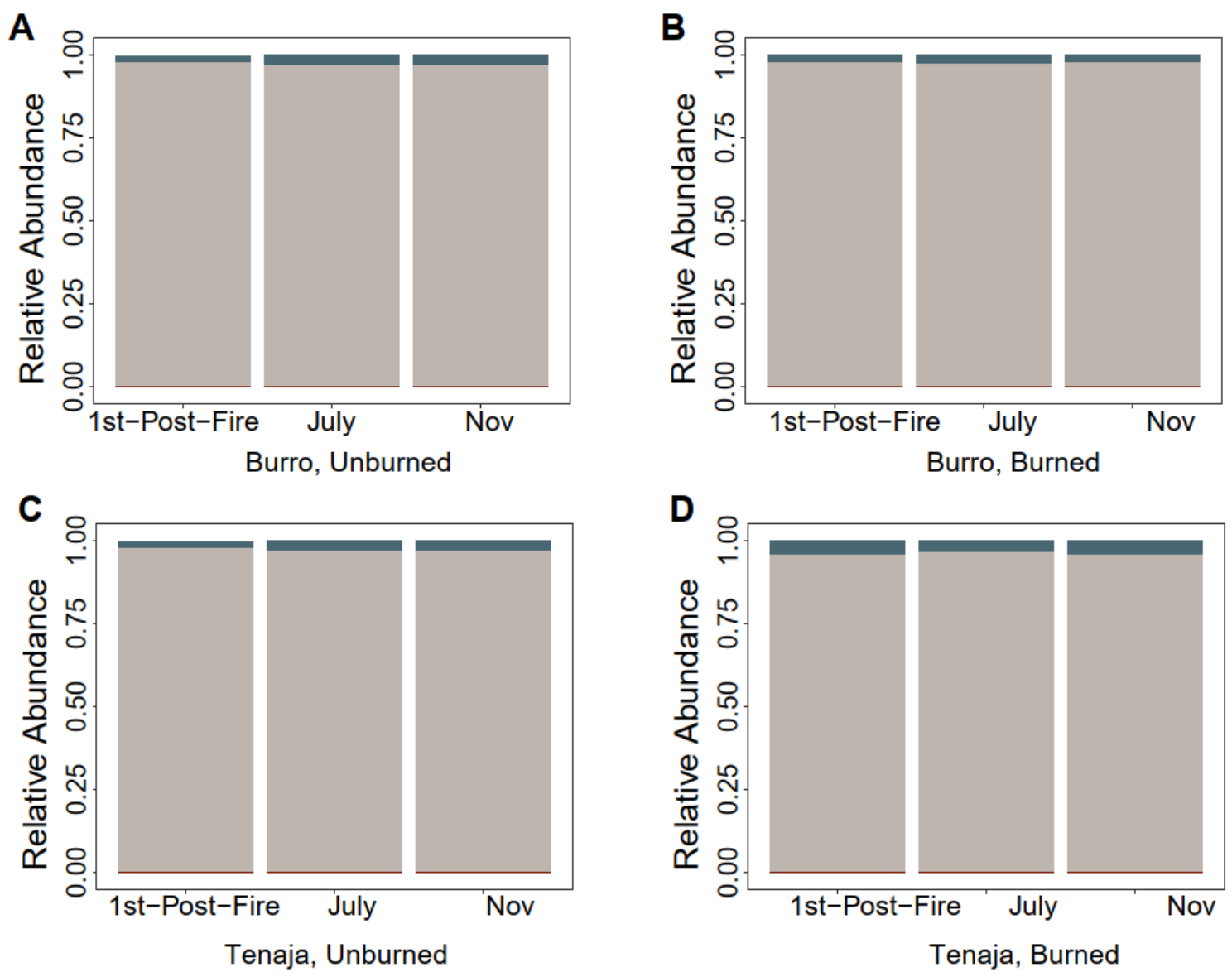

Kingdom Archaea Bacteria $\square$ Unassigned 
Fig. S3. Relative sequence abundance of bacterial phyla in the Burro prescribed fire A) unburned plots and $B$ ) burned plots and in the Tenaja wildfire $C$ ) unburned and D) burned plots at the three time points.
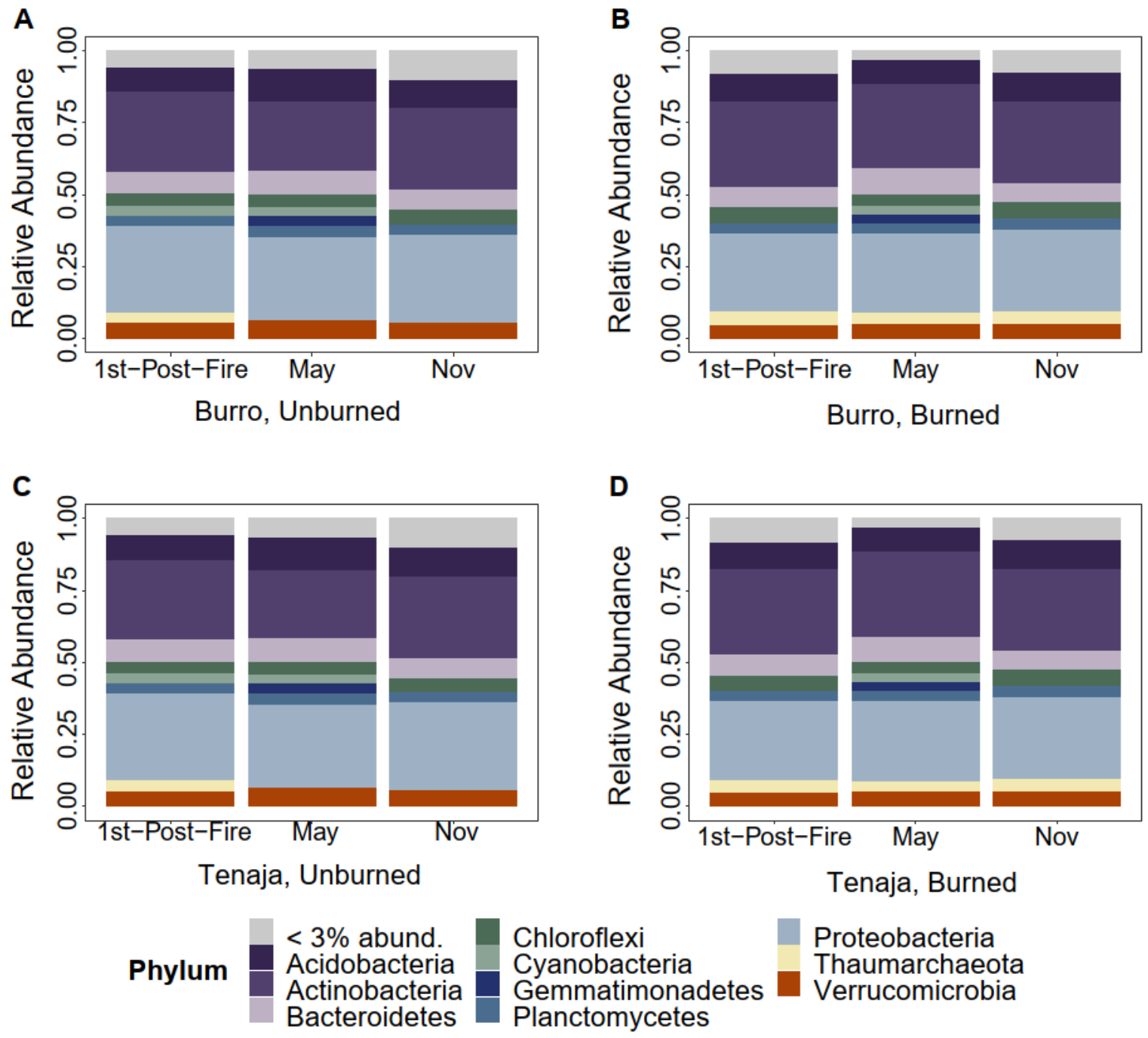
Fig S4. Relative sequence abundance of fungal phyla in the Burro prescribed fire A) unburned plots and $B$ ) burned plots and in the Tenaja wildfire $C$ ) unburned and D) burned plots at the three time points.
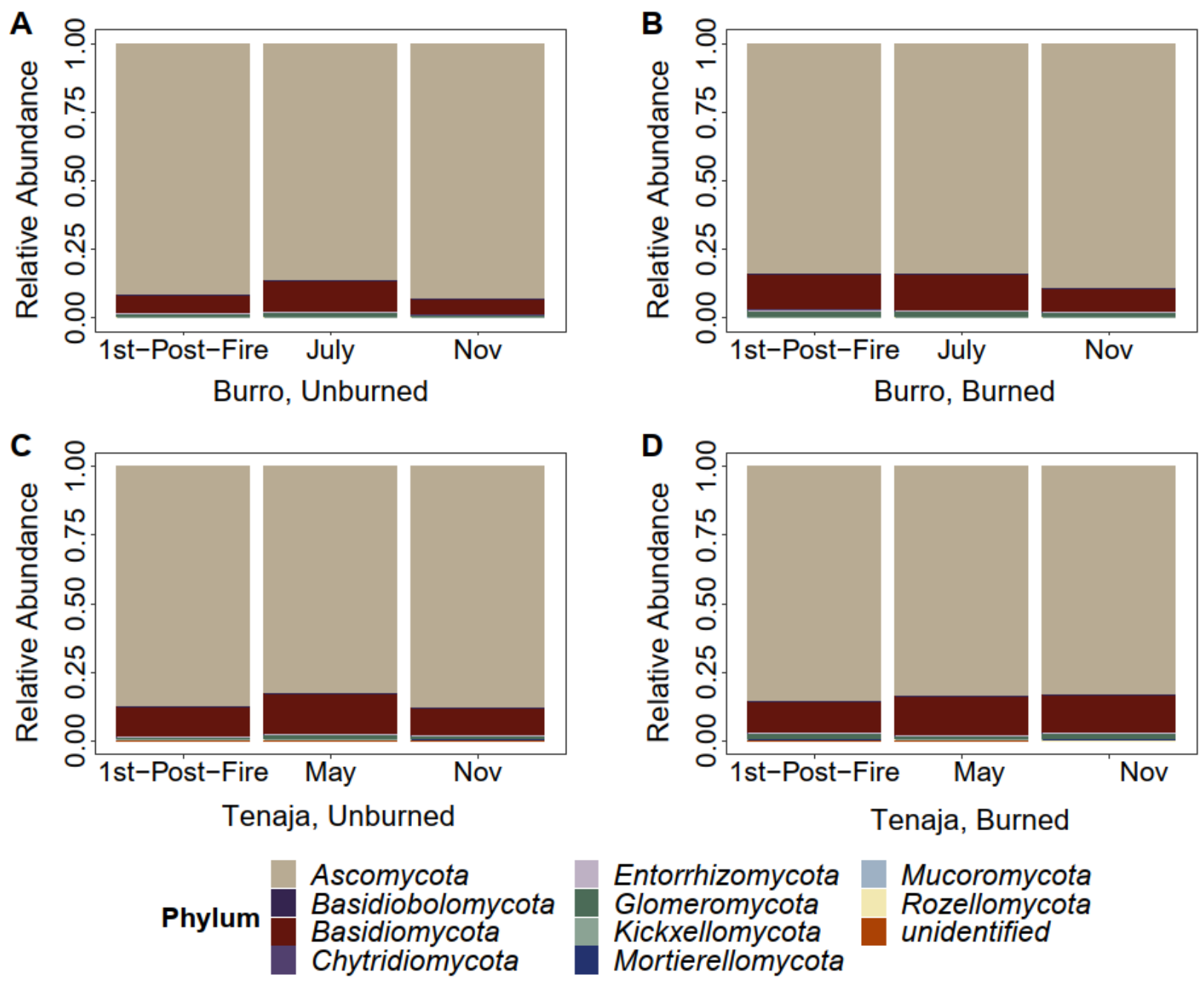
Fig S5. Relative sequence abundance of fungal families in the Burro prescribed fire A) unburned plots and B) burned plots and in the Tenaja wildfire C) unburned and D) burned plots at the three time points. Burro samples and in C) unburned Tenaja versus D) burned Tenaja samples.

A

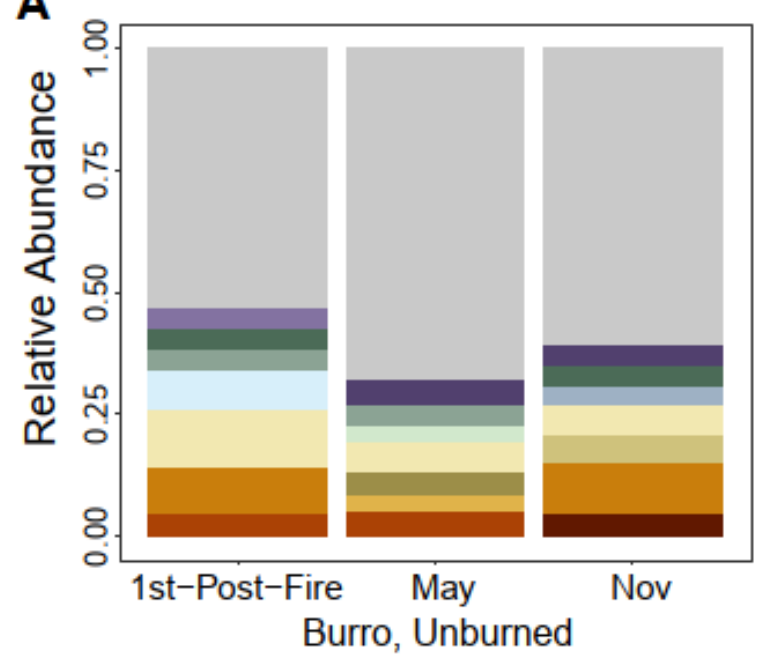

C

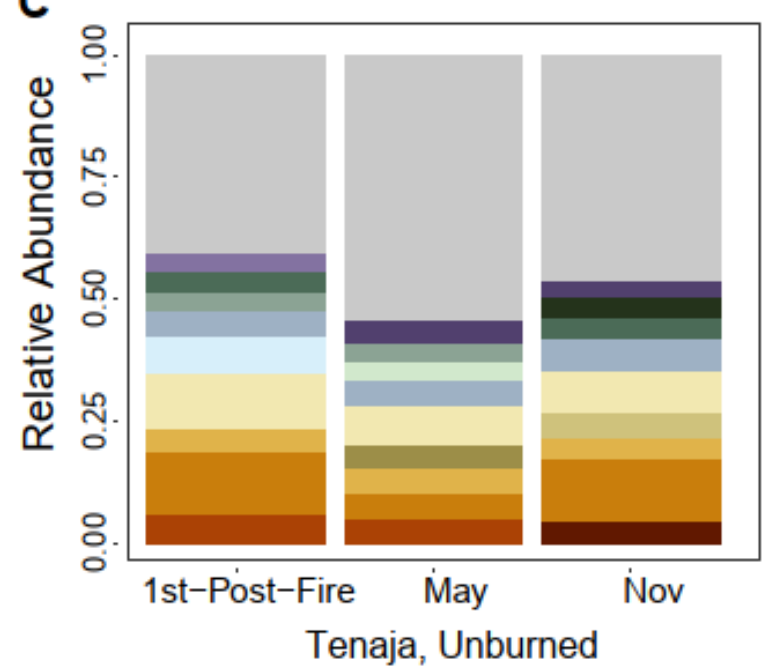

Family

$<3 \%$ abund. Aspergillaceae

Bionectriaceae

Bolbitiaceae

Chaetomiaceae

Cladosporiaceae
Coniochaetaceae Diaporthaceae

Geastraceae

Entolomataceae

Helotiaceae

Herpotrichiellaceae

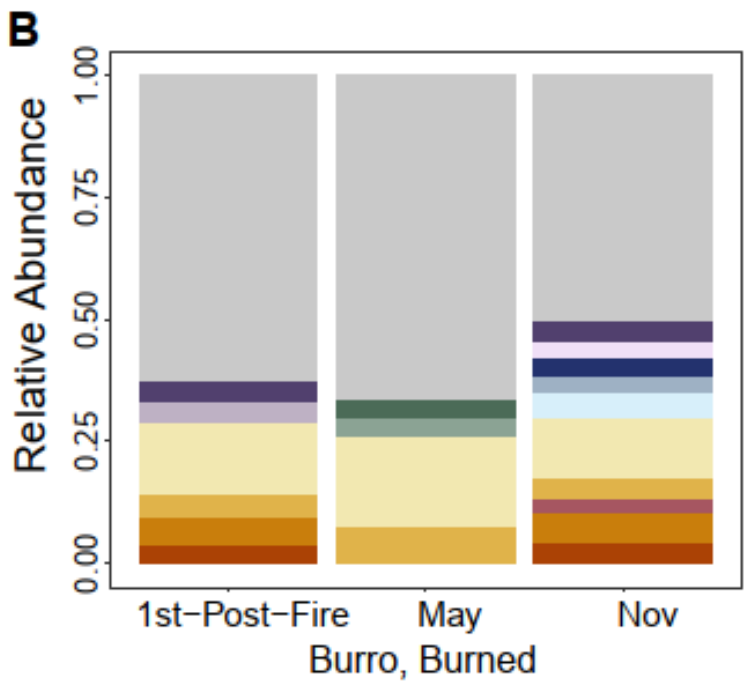

D

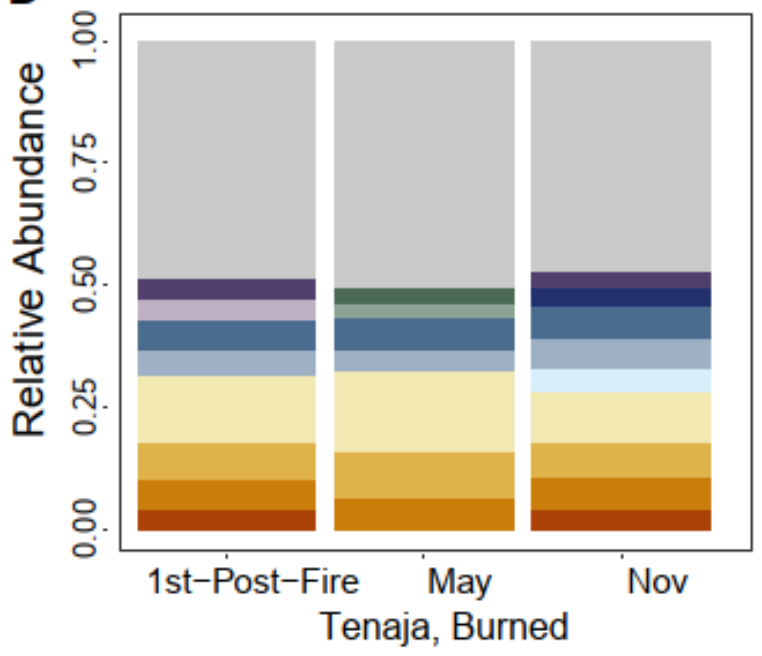

Hydnodontaceae Lasiosphaeriaceae Lophiostomataceae Mycosphaerellaceae Nectriaceae

Phacidiaceae
Pleosporaceae

Rutstroemiaceae Thelephoraceae 
Methods S1: Description of molecular methods for obtaining $16 \mathrm{~S}$ and ITS amplicon sequencing libraries.

For fungi, we combined the gene-specific primers (ITS4-fun and 5.8s; Taylor et al. 2016) at $0.5 \mu \mathrm{l}$ each at $10 \mu \mathrm{M}, 5 \mu \mathrm{l}$ of undiluted fungal DNA, $6.5 \mu \mathrm{l}$ of Ultra-Pure Sterile Molecular Biology Grade (Genesee Scientific, San Diego, CA, USA) water and $12.5 \mu \mathrm{l}$ of AccuStart ToughMix (Quantabio, Beverly, MA, USA). Thermocycler conditions were: $94^{\circ} \mathrm{C}$ for $2 \mathrm{~min}$, followed by 31 cycles of $94{ }^{\circ} \mathrm{C}$ for $30 \mathrm{~s}, 55^{\circ} \mathrm{C}$ for $30 \mathrm{~s}, 68^{\circ} \mathrm{C}$ for $2 \mathrm{~min}$ followed by a 10 min extension at $68^{\circ} \mathrm{C}$. For bacteria, we combined $1 \mu \mathrm{l}$ of 1:10 diluted DNA, 10.5 $\mu$ l of water, $12.5 \mu \mathrm{l}$ of AccuStart ToughMix

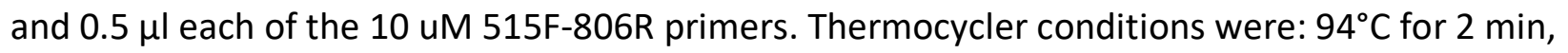
followed by 30 cycles of $94^{\circ} \mathrm{C}$ for $30 \mathrm{~s}, 55^{\circ} \mathrm{C}$ for $30 \mathrm{~s}, 68^{\circ} \mathrm{C}$ for $1 \mathrm{~min}$ followed by a $2 \mathrm{~min}$ extension step for at $68^{\circ} \mathrm{C}$. Both conditions ended with a $4^{\circ} \mathrm{C}$ hold. PCR products were then cleaned with AMPure XP magnetic Bead protocol (Beckman Coulter Inc, Brea, CA, USA) following manufacturers protocols. The DIP PCR2 primers containing the barcodes and adaptors for Illumina sequencing were ligated to the amplicons during the second PCR step in a $25 \mu \mathrm{L}$ reaction containing $2.5 \mu \mathrm{l}$ of the $10 \mathrm{uM}$ DIP PCR2 primers, $6.5 \mu \mathrm{l}$ of water, $12.5 \mu \mathrm{l}$ of Accustart ToughMix and $1 \mu \mathrm{l}$ of PCR 1 product. Thermocycler conditions for the second PCR were: $94^{\circ} \mathrm{C}$ for $2 \mathrm{~min}$ followed by 10 cycles of $94^{\circ} \mathrm{C}$ for $30 \mathrm{~s}, 60^{\circ} \mathrm{C}$ for $30 \mathrm{~s}, 72^{\circ} \mathrm{C}$ for $1 \mathrm{~min}$, and finally ending at a $4^{\circ} \mathrm{C}$ hold. Bacterial and fungal PCR products were then separately pooled based on gel electrophoresis band strength and cleaned with AMPURE following established methods (Glassman et al. 2018). The $16 \mathrm{~S}$ and ITS pools were each checked for quality and quantity with an Agilent 2100 Bioanalyzer, then pooled at 0.4 bacteria to 0.6 fungi ratio prior to sequencing. 
Methods S2. Methodological details for qPCR reactions to obtain estimates of bacterial and fungal biomass

Bacterial biomass was estimated based on bacterial 16S rRNA genes using the Eub338/Eub518 primer set (Fierer et al. 2005) and fungal biomass was estimated based on fungal 18S rRNA genes using the FungiQuant-F and FungiQuant-R primer set (Liu et al. 2012). qPCR reactions were performed in triplicate with $1 \mu \mathrm{L}$ of undiluted DNA added to $9 \mu \mathrm{l}$ of qPCR master mixer containing $1 \mu \mathrm{l}$ of $0.05 \mathrm{M}$ Tris- $\mathrm{HCl}$ ph8.3, $1 \mu \mathrm{L}$ of $2.5 \mathrm{mM} \mathrm{MgCl}_{2}$ (New England BioLabs; NEB; Ipswich, MA, USA), $0.5 \mu \mathrm{L}$ of $0.5 \mathrm{mg} / \mathrm{ml}$ BSA , $0.5 \mu \mathrm{L}$ of $0.25 \mathrm{mM}$ dNTPs (NEB), $0.4 \mu \mathrm{L}$ of both forward and reverse primer at $0.4 \mu \mathrm{M}, 0.5 \mu \mathrm{L}$ of $20 \mathrm{X}$ Evagreen Dye (VWR), $0.1 \mu \mathrm{L}$ of Taq DNA polymerase (NEB) and the remaining volume of $4.6 \mu \mathrm{L}$ with the molecular grade water. Each reaction was run in triplicate in 384 well plates on CFX384 Touch Real-Time PCR Detection System starting at $94^{\circ} \mathrm{C} 5 \mathrm{~min}$, followed by 40 cycles of a denaturing step at $94^{\circ} \mathrm{C} 20 \mathrm{sec}$, primer annealing at $52^{\circ} \mathrm{C}$ for bacteria or $50^{\circ} \mathrm{C}$ for fungi at $30 \mathrm{sec}$, and an extension step at $72^{\circ} \mathrm{C}$ for 30 sec. Standards were generated by cloning the $18 \mathrm{~S}$ region of Saccharomyces cerevisiae or the $16 \mathrm{~S}$ region of Escherichia coli into puc57 plasmid vectors, which were constructed by GENEWIZ, Inc. (NJ, USA) as previously established (Averill \& Hawkes 2016) Melt curves were generated and copy number extracted using the following equation: $10^{(\mathrm{Cq}-\mathrm{b}) / \mathrm{m}}$ where $\mathrm{Cq}$ is the average of 3 technical replicates of $\mathrm{Cq}$ value and $\mathrm{b}$ is the $\mathrm{y}$ intercept and $\mathrm{m}$ is the slope.

Averill, C. \& Hawkes, C.V. (2016) Ectomycorrhizal fungi slow soil carbon cycling. Ecology Letters, 19, 937-947.

Fierer, N., Jackson, J.A., Vilgalys, R. \& Jackson, R.B. (2005) Assessment of soil microbial community structure by use of taxon-specific quantitative PCR assays. Applied and Environmental Microbiology, 71, 4117-4120.

Glassman, S.I., Weihe, C., Li, J.H., Albright, M.B.N., Looby, C.I., Martiny, A.C., Treseder, K.K., Allison, S.D. \& Martiny, J.B.H. (2018) Decomposition responses to climate depend on microbial community composition. Proceedings of the National Academy of Sciences of the United States of America, 115, 11994-11999.

Liu, C.M., Kachur, S., Dwan, M.G., Abraham, A.G., Aziz, M., Hsueh, P.R., Huang, Y.T., Busch, J.D., Lamit, L.J., Gehring, C.A., Keim, P. \& Price, L.B. (2012) FungiQuant: A broad-coverage fungal quantitative real-time PCR assay. Bmc Microbiology, 12. 